\title{
Science and serendipity
}

\author{
Mark B Pepys
}

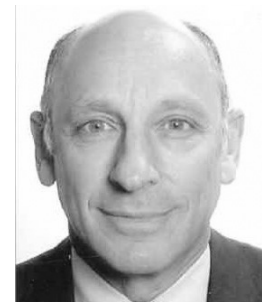

The Harveian Oration is given annually at the Royal College of Physicians of London under an indenture of William Harvey of 1656. This article

is based on the 2007 oration given on 18 October by

Mark B Pepys MD PhD FRCP FRCPath FRS FMedSci,

Professor and Head of Medicine at the Hampstead Campus, University College London; Director, Centre for Amyloidosis and Acute Phase

Proteins, Royal

Free \& University

College Medical School

\begin{abstract}
Good science demands independent replication of new ideas and results and abandonment of accepted theories in light of more reliable evidence. Failure to comply leads to damaging bad science, as with the falsely claimed association between measles, mumps and rubella vaccination and autism. Progress of good science also often requires serendipity, 'making discoveries by accident and sagacity of things not sought'. Work on the pentraxin proteins, C-reactive protein (CRP) and serum amyloid $P$ component (SAP), and on amyloidosis, has benefited from abundant serendipity, leading to routine clinical use of CRP measurements, the invention of SAP scintigraphy for amyloidosis, the establishment of the NHS National Amyloidosis Centre providing superior patient care, and latterly the invention of a novel pharmacological mechanism for therapeutic depletion of pathogenic proteins. New drugs using this mechanism are in development for amyloidosis and cardiovascular disease and potentially also Alzheimer's disease, type II diabetes and other tissue damaging conditions.
\end{abstract}

KEY WORDS: amyloidosis, C-reactive protein, serum amyloid $\mathrm{P}$ component

\section{The nature of science}

What is science? An excellent definition is given by EO Wilson: 'Science is the systematic enterprise of gathering knowledge about the world and organising it and condensing that knowledge into testable laws and theories.' ${ }^{1}$ In order for a claim or observation to be considered rigorously scientific it must be testable experimentally and must accurately predict how the relevant aspect of the world works. Robert Park, an eminent physicist and director of the Washington office of the American Physical Society, succinctly observes that if either condition is not met then:

\footnotetext{
...it isn't science. The success and credibility of science are anchored in the willingness of scientists to obey two rules: 1. Expose new ideas and results to independent testing and replication by other scientists. 2. Abandon or modify accepted facts and theories in the light of more complete or reliable evidence. ${ }^{2}$
}

The late great Richard Feynman, in his famous Commencement address at Stanford in 1974, spoke about the underlying philosophy of science:

It's a kind of scientific integrity, a principle of scientific thought that corresponds to a kind of utter honesty - a kind of leaning over backwards. For example, if you're doing an experiment, you should report everything that you think might make it invalid - not only what you think is right about it: other causes that could possibly explain your results; and things you thought of that you've eliminated by some other experiment, and how they worked - to make sure the other fellow can tell they have been eliminated.

Details that could throw doubt on your interpretation must be given, if you know them. You must do the best you can - if you know anything at all wrong, or possibly wrong - to explain it. If you make a theory, for example, and advertise it, or put it out, then you must also put down all the facts that disagree with it, as well as those that agree with it. There is also a more subtle problem. When you have put a lot of ideas together to make an elaborate theory, you want to make sure, when explaining what it fits, that those things it fits are not just the things that gave you the idea for the theory; but that the finished theory makes something else come out right, in addition.

In summary, the idea is to try to give all of the information to help others to judge the value of your contribution; not just the information that leads to judgment in one particular direction or another.

The easiest way to explain this idea is to contrast it, for example, with advertising. ${ }^{3}$

We all easily recognise commercial advertising but it is particularly important to identify advertising masquerading as science.

Rigorous science and the scientific method are immensely powerful, and have been responsible for all progress in modern medicine and beyond. I will not provide examples or otherwise defend that statement in this College and before this audience because the case has been extensively rehearsed elsewhere, most recently in the outstanding 'Sense about Science' lecture given in March 2007 by Raymond Tallis. ${ }^{4}$ Rather, I wish to focus on the difference between good science, which can be a majestic expression of the highest achievement of the human intellect and spirit, and bad science, which is misleading, wasteful, often damaging and sometimes lethal.

A necessary condition for good science is that it must function within the strict guidelines of the 
scientific method, including rigour, honesty, reproducibility and a willingness to change or abandon the status quo when it is overturned by new knowledge. Nevertheless, despite these constraints, science is not a mechanical process and can be wonderfully exciting and creative. Success demands much: the preexisting knowledge base and the work of others, creative insight either to see a new question or envisage a new answer, and it also needs luck - hence the contribution of serendipity to which I will return later. Unfortunately, the downside of the scientific method is its inherent conflict with essential features of human cognitive function, as shaped by evolution.

There is clearly substantial survival value in comprehension of cause and effect relationships in our interactions with the physical world, and the apparent default position for human cognition is the automatic assumption that if two events are temporally related, the second is caused by the first. Until the advent of modern science, ushered in by Harvey's observational, evidencebased analysis, explanations of the world other than simple post hoc ergo propter hoc were either acts of religious faith or a belief in witchcraft and superstition. The beauty of science in relation to the physical world is that it works and in many cases so compellingly that there is, or should be, no room for argument. It is incontrovertible that the availability of fresh citrus fruit on long sea voyages prevented scurvy, that a clean water supply prevents transmission of enteric infections, or that vaccination prevents many infectious diseases. Of course, there is always room for argument in some situations, for example with respect to cost, risk:benefit ratio, personal versus societal and other sociological considerations, and so on, but most of these issues can also all be most appropriately handled using scientific methodology. Failure to apply rigorous scientific principles leads to the many varieties of bad science.

\section{Bad science}

Robert Park's penetrating analysis in his book Voodoo science the road from foolishness to fraud recognises a slippery slope of bad science comprising distinct but overlapping categories. ${ }^{2}$

Pathological science is observing what the author expects or wants to see (the antithesis of Feynman's description of scientific impartiality), reaching thereby an erroneous conclusion and then having it accepted by others. Acceptance of pathological science is all too easy, often starting from the intrinsic qualities of human nature and cognition, which, as noted above, are evolutionarily programmed to conflate association and causality. It can then be strongly fostered by an emotive topic and a charismatic proponent, achieve prominence through inadequate refereeing and editing in scientific journals, and finally be ignited by the popular media, which mostly lack scientific competence and where the rampant desire for a story disregards the consequences.

Junk science comprises crafted 'evidence', usually along the lines of 'what could be so', and often with its credibility for the media and the public enhanced by conflation of association and causality. The fact that the cock crows shortly before the sun comes up each day does not mean that the cock crowing causes the sun to rise. Relatively few in the developed world today would think it does, but much of the abundant junk science which is rampant in our society is just as ridiculous. Most people are also strangers to the concept of reverse causality, in this case that the sun rising is what causes the cock to crow.

Pseudoscience consists of apparently scientific sounding statements and beliefs comprising claims and assertions, with no evidence at all. Homeopathy is a good example, in which therapeutic efficacy is claimed for such dilute preparations of the 'active' ingredients that the preparation is, in fact, no different from water or other excipients.

Park includes all these varieties of bad science under the term 'voodoo science' and traces its downward spiral from foolishness to frank fraud, in which fake or mendacious 'evidence' is provided to support the claims. Although bad science starts with the initial perpetrators of pathological, junk, pseudo- and fraudulent science, the problem is greatly exacerbated by the combination of poor scientific literacy in the general population and in the media, and by the patchy performance of supposedly reputable scientific journals. Editors hungry for high impact articles, and reviewers who are less than adequately knowledgeable, experienced or critical, can lead to publication of really bad science in respected journals. If the case happens to have medical or public health impact the attendant consequences can be extremely serious. Publication of a sensational or scary story in a journal inevitably leads to promotion by the media, often fostered by the original authors.

\section{Cardiac risk publicity}

Here is an entertaining example from my own field, involving $\mathrm{C}$-reactive protein (CRP) on which I have been working since 1974. C-reactive protein is the classical acute phase plasma protein which increases in concentration completely nonspecifically in response to most forms of tissue injury, infection and inflammation. ${ }^{5}$ In 1994, in collaboration with Attilio Maseri, we reported in the New England Journal of Medicine on the prognostic significance of even minor increases in CRP values in patients with severe unstable angina. ${ }^{6}$ Soon afterwards we and others observed prognostic significance for coronary heart disease of increased baseline CRP values in our patients with angina ${ }^{7}$ and in the general population. ${ }^{8-11}$ These findings triggered an avalanche of interest in CRP in cardiovascular disease. The field is very controversial but, in the best scientific tradition, the accumulation of robust evidence will eventually (and probably quite soon) settle the issues by establishing reproducibly the actual relationships, the genuine effects of CRP and the clinical utility of its measurement in this context. ${ }^{12,13}$ Meanwhile, the media have taken it up enthusiastically. Here is a classic title to an article from The Times of 21 January 2003: 'The real cause of heart attacks? CRP could be more dangerous than cholesterol, says Jerome Burne'. You will not find many 
peer-reviewed papers about CRP by Mr Burne listed on PubMed but he was just hyping the published work of prominent researchers. There has been so much of this that I have been tempted to reassign the abbreviation CRP to the term 'cardiac risk publicity' but actually I prefer another use of CRP, standing for 'crucial revelations from Pepys' a euphonious phrase coined by my friend Dr Felix Wyler, a Swiss cardiologist. I can confidently reassure you that CRP is not more dangerous than cholesterol although, as we have clearly shown in experimental models, CRP can exacerbate the ischaemic tissue damage of acute myocardial infarction (AMI) and stroke. ${ }^{14,15}$ However, passions run high in this field and when we published a study showing that transgenic expression of human CRP did not have any effect on development of atherosclerosis in apolipoprotein $\mathrm{E}$ knockout mice, ${ }^{16}$ there was a furious response from some quarters. Steve Nissen, lately in the news for his controversial assessment of Avandia ${ }^{\circledR}$ (rosigliatazone) and cardiovascular disease risk, had this to say:

There is good evidence that CRP plays a pathophysiological role. To say there is no evidence for a causal role is ridiculous. Many nihilists fought vociferously against the concept of LDL [low density lipoprotein] as a causative agent in atherosclerosis. A few of them still don't accept the concept. ${ }^{17}$

Nissen's 'good evidence' for pathogenicity of CRP in atherosclerosis comprises, first, the conflation of epidemiological association with causality and, second, claims for effects of CRP based on uncontrolled in vitro studies using contaminated CRP preparations produced in recombinant bacteria. ${ }^{18-20}$ The beauty of good science is that the rigorous reproducible evidence will emerge and extinguish erroneous beliefs, however firmly held, as happened with low density lipoprotein and cholesterol, which do, of course, cause atherosclerosis. The true strength and quality of the epidemiological relationship between baseline CRP values and cardiovascular disease risk will soon be revealed by the Emerging Risk Factors Collaboration led by John Danesh, ${ }^{21}$ while extensive Mendelian randomisation epidemiology together with further pathobiological studies will demonstrate whether or not CRP contributes to pathogenesis of atherosclerosis and/or atherothrombosis. ${ }^{13}$

\section{Measles, mumps, and rubella vaccination}

A very much more serious example is the campaign against combined measles, mumps, and rubella (MMR) vaccination. An imagined association between MMR and autism was portrayed as causal but without a credible mechanism. The absence of an explanation consistent with any generally accepted scientific knowledge would not have mattered if there had been some, or even any, rigorous and reproducible experimental or epidemiological evidence in support of either the purported association or a potential causal mechanism linking MMR vaccination to the adverse effects claimed for it. Despite complete absence of any such evidence, once the idea was published in The Lancet and elsewhere, it has proved unstoppable. Raymond Tallis, writing earlier this year in The Times, puts it very clearly:
An instructive instance was the panic over the supposed connection between the MMR vaccine and autism. Careful studies of millions of children who had been immunised, which showed no causal link were regarded as somehow tainted, while the views of junk scientists, and of celebrities whose ignorance was matched only by their reckless irresponsibility, were accepted quite uncritically. In the end, science won out but it was a close-run thing and the argument was unconscionably protracted. Even now the Daily Mail is not convinced. ${ }^{22}$

Tragically it is not just the Daily Mail, but does it matter? The answer is, yes it does.

The single measles vaccine programme had poor uptake; control of measles was only achieved with MMR, and a second dose is essential to prevent resurgence of infection. Furthermore, elimination of congenital rubella was only achievable with MMR, which has also substantially reduced the 1,400 annual hospital admissions for mumps, mostly for meningitis. Congenital rubella, mumps meningoencephalitis, orchitis and ovariitis are not trivial conditions.

The terrible cost of vaccine scares is well documented and should have engendered more appropriate rigour and caution among those promulgating and publishing this one. The scare about pertussis (whooping cough) vaccine led to provision of separate diphtheria+tetanus and pertussis vaccines which undermined confidence in the programme. Vaccination against whooping cough had reduced the number of cases per year in England and Wales from between about 60,000 and 170,000 to about 2,000 per year, but after the scare there were over 200,000 reported cases and an estimated 100 deaths. Despite assertions to the contrary by the MMR scaremongers, measles is also not a trivial condition. It maims and kills a small, but not insignificant, proportion of children in developed countries. In the Netherlands outbreak of 1999-2000, 3,250 cases of measles were notified, $97 \%$ of which were in the unvaccinated Dutch Reformed community, around $20 \%$ had serious complications, including five cases of encephalitis and three deaths. In the Irish outbreak of 2000, which occurred as a direct result of lower vaccination rates following the MMR scare which reduced coverage to just $74 \%$, there were 1,500 notified cases and three deaths. There continue to be cases of measles due to poor MMR coverage and, tragically, two children who had undergone renal transplantation in London have been severely and irreparably damaged by measles encephalitis. ${ }^{23}$

In contrast, MMR vaccination is remarkably safe. ${ }^{24,25}$ In addition to the published studies cited here and the reviews at each meeting of the Committee on Safety of Medicines (CSM) and of the Joint Committee on Vaccination and Immunisation, comprehensive expert panels convened by the Medical Research Council (MRC) (twice), the CSM, the American Academy of Pediatrics, the Scottish Executive, the Irish Parliament, the British Medical Journal, the World Health Organization (WHO) and the Institute of Medicine (Washington, DC), have reviewed all the available evidence and all have concluded that there is no evidence of a link between MMR and autism. MMR vaccination does not cause autism. ${ }^{7,24-37}$ Nor does it cause subacute sclerosing panencephalitis, ${ }^{38}$ gait disturbance ${ }^{39}$ or 'immune overload' ${ }^{40}$ 
Figure 1. Contrast between the landscape of (a) Novaya Zemlya (Nova Zembla) and (b) Sri Lanka (Serendip). (a) Satellite image by NASA - J Schmaltz, MODIS LRRT (public domain); (b) copyright @ $\mathrm{J}$ Claydon 2007.
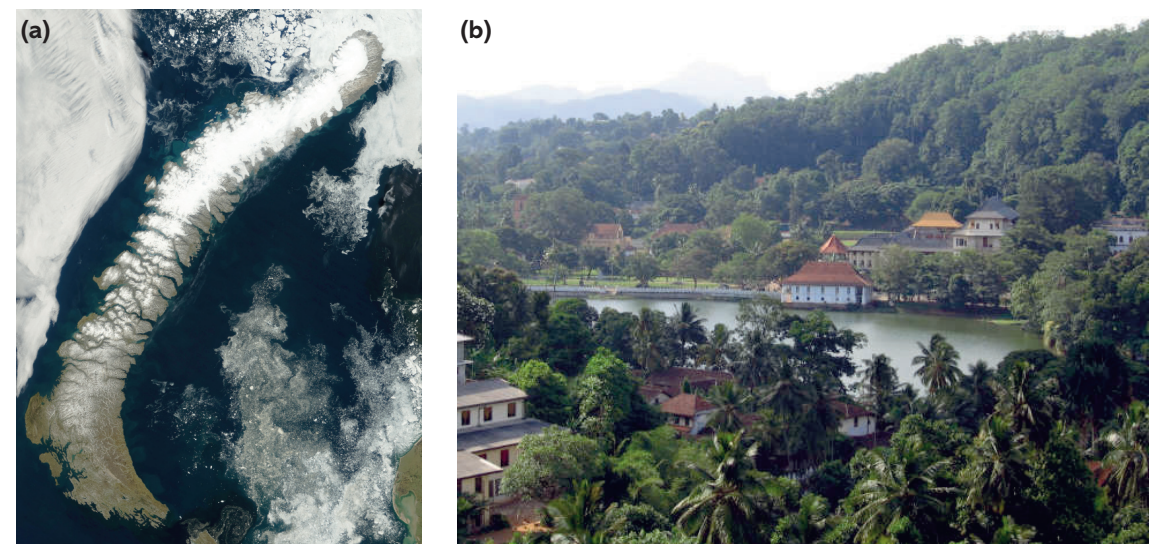

Furthermore, there is no evidence for adverse effects of thiomersal, ${ }^{41-45}$ another target of the vaccination scaremongers. The actual side effects of MMR vaccination in children are: mild fever, rash, and anorexia for 6-11 days in 10\% (from the measles component); parotid swelling at 2-3 weeks in 1\% (from the mumps component); 1 per 1,000 risk of febrile convulsion around 6-11 days (from the measles component); 1 per 24,000 risk of thrombocytopaenic purpura within 2-6 weeks (from the measles or rubella component); 1 per $10^{5}$ risk of allergic reaction; possible 1 per $10^{6}$ risk of encephalitis.

In the less developed countries, measles is a major killer and was responsible for an estimated six million deaths annually worldwide before introduction of the measles vaccine in the 1960s. More recently, according to WHO figures, annual deaths had fallen by $60 \%$ from 873,000 during 1999 to 345,000 at the end of 2005. Results in Africa are even better with deaths there declining by $75 \%$ while global measles deaths in children under five fell from 791,000 to 311,000 over the same period. Altogether, measles vaccinations have prevented 7.5 million deaths between 1999 and 2005, and 2.3 million of these were attributable to the intensified MMR programme of the WHO. What a powerful illustration of the stark contrast between good science that works and bad science that can kill.

\section{Serendipity}

Bad science in its various guises is the opposite of the serendipity which so wonderfully enables and enriches good science. The history of scientific and medical discovery is replete with examples of serendipity. So what is it? The word was coined by Horace Walpole in a letter dated 28 January 1754 to his friend Horace Mann, an Englishman then living in Florence. It derives from his analysis of events in a fairy tale entitled The Three Princes of Serendip, Serendip being the ancient name for Sri Lanka. The simplest definition of serendipity is 'making discoveries, by accident and sagacity, of things not sought'. Walpole wrote:

One of the most remarkable instances of this accidental sagacity (for you must observe that no discovery of a thing you are looking for, comes under this description) was of my Lord Shaftsbury, who happening to dine at Lord Chancellor Clarendon's, found out the marriage of the
Duke of York and Mrs Hyde, by the respect with which her mother treated her at table.

Many distinguished individuals have commented on serendipity in science. For example:

- Louis Pasteur: 'In the field of observation, chance favours only the prepared mind'.

- Isaac Asimov: 'The most exciting phrase to hear in science, the one that heralds new discoveries, is not "Eureka!", but "That's funny...".

- Julius Comroe Jr: 'Serendipity is looking in a haystack for a needle and discovering a farmer's daughter'.

\section{Zemblanity and bahramdipity}

Less generally familiar but nonetheless useful words have subsequently been coined to describe related, but contrary, phenomena in science and life in general. William Boyd derived the term zemblanity, meaning the opposite of serendipity, from the name of the Russian Arctic island, Novaya Zemlya (or Nova Zembla), a cold barren land starkly contrasting with the lush and beautiful Serendip (Sri Lanka) (Fig 1). Zemblanity is 'making unhappy, unlucky and expected discoveries occurring by design'. ${ }^{46}$ Nova Zembla was where William Barents and his crew were stranded while searching for a new route to the East and the aptness of its choice for this metaphor was enhanced by its subsequent use as the major site of Soviet nuclear testing. I shall return later to some examples of zemblanity.

In his 2001 article, Toby Sommer coined two other new words. ${ }^{47}$ The first, bahramdipity, derives from Bahram Gur, the vicious totalitarian Persian dictator who appears in the The Three Princes of Serendip, and is defined as:

\footnotetext{
1. The suppression of a discovery, sometimes a serendipitous discovery, by a more powerful individual (bahram) who does cruelly punish, not merely disdain, a person (or persons) of lesser power and little renown who demonstrates sagacity, perspicacity and truthfulness to the bahram. 2. The self serving promotion of an often unreliable discovery and its discoverer by a more powerful individual (bahram).
}

An example of the latter is the irresponsible publication of a publicity seeking article by a journal editor. Sommer's second word is nulltiple: 'a scientific discovery published zero times' 
and arises because 'bahramdipitous discoveries are suppressed or not even allowed to be completed or verified. They are almost always not published in the normal peer reviewed literature and remain undiscovered by others'.

Nulltiples, by their very nature, may never come to light but there are some well documented examples of bahramdipity in the history of science, and regrettably some of you may be aware that it exists or even have experienced it. However, lest there should be any confusion about the concept, Sommer emphasises that:

\section{Bharamdipity should not be used to describe the suppression of non- verifiable, certifiably false claims of misguided or deliberately deceptive researchers. There are many accounts of such works. ${ }^{47}$}

Good science demands the capacity to objectively distinguish between bahramdipity and the rigorous objective use of the scientific method to evaluate results and claims. Assertions of bahramdipity are no defence against appropriate application of the cardinal scientific principles of independent testing and replication, coupled with abandonment of a theory in light of more complete or reliable evidence, as should have happened much more swiftly and decisively with the MMR affair.

\section{Tone deafness to science}

The present pervasive deficiency in scientific understanding among the majority of the population is a tragic example of zemblanity. Lack of exposure to science and grossly inadequate scientific education in schools has created a population which is as effectively cut-off from understanding science and how it operates as a totally tone deaf individual is cut-off from appreciation and enjoyment of music. This is a terrible deprivation. The many individuals in our society who are tone deaf to science enable junk science, avidly taken up and promoted by much of the media, to effortlessly take root and flourish, often very damagingly.

\section{More serendipity}

All, however, is not doom and gloom. Good science continues to subtend our increasingly technological society, including the exhilarating progress of modern medicine. Serendipitous events and observations frequently underpin these developments but are rarely reported in the formal scientific literature. I have personally benefited greatly from serendipity and wish here both to acknowledge my good fortune and to illustrate how it has directed and enabled my scientific work. I am also fortunate to have suffered only a modicum of zemblanity and to have avoided any bahramdipity, at least so far.

The starting point, of course, involves none of these concepts, but rather the deliberate choice of one's parents and here I congratulate myself on having done a very good job. They provided all and more than could have been asked of them. It is neither trite nor obvious to acknowledge gratefully both their general responsibility for my presence here tonight and specifically the unique mentorship of my late father, Professor Jack Pepys FRCP. However I chose my own areas of research which have largely focused on just a few circulating plasma proteins, in particular the pentraxins, CRP and serum amyloid P component (SAP), and through the latter on amyloidosis. Despite this focus, studying the structures, functions and roles in disease of these molecules, and also their clinical significance and utility in diagnosis and treatment has made me a promiscuous globetrotter across much of pathobiology and medicine. I arrived in this field entirely by chance but it has been fruitful and I have spoken about these molecules in my 1982 Goulstonian and 1998 Lumleian lectures at the College. I will do so again now and doubtless those of you still sentient after all this will be grateful that there is not another lecture after the Harveian.

The ultimate goal of biomedical research is to have a beneficial impact on the health and welfare of patients, by elucidation of aetiology and pathogenesis of disease, improved diagnostics and management and by creation of new and more effective medicines. Together with many colleagues and collaborators over the years, I have been fortunate enough to contribute across these areas but lately our work is most energetically centred on design and development of novel therapies. In tracing parts of the path towards this goal, I will highlight some of the many episodes of good fortune which have cleared the way.

\section{Complement component $\mathrm{C} 3$}

Before getting involved with the pentraxins and amyloidosis I worked on the third component of complement, C3. This came about as a result of two happy accidents. First, the PhD project on complement which had been assigned to me turned out, after a couple of months' work, to be based on an artefact so I abandoned it. Second, my supervisor departed for a sabbatical abroad leaving me free to come up with my own original idea. Complement had long been known as an effector system activated by antibodies and contributing both to host defence and to inflammation and tissue damage. In the late 1960s receptors for the C3 component of complement had been discovered on lymphocytes and macrophages, and C3 had also been found in the germinal centres of lymphoid follicles where antigens are trapped and retained and where lymphocyte cooperation leading to antibody production takes place. I hypothesised that complement and especially C3 might be involved in the induction of antibody formation, that is the processes following exposure to antigen and leading to antibody formation, rather than just as an effector after antibody production had occurred. A powerful tool to test the idea existed in the form of a protein in cobra venom which harmlessly and completely depletes circulating C3 in vivo. I used this to demonstrate that C3 depleted mice failed to mount normal antibody responses (Fig 2) or to localise antigens to lymphoid follicles and, together with other in vitro and in vivo experiments, established that complement does indeed participate in the induction of antibody formation. ${ }^{48-56}$ The intersection and cross talk between innate and acquired immunity is universally recognised nowadays but it was revolutionary 35 years ago and took some time to be appreciated, although the original observations were solidly reproducible in patients and animals with naturally occurring inher- 
Figure 2. Effect of $\mathrm{C} 3$ depletion by cobra factor (CoF) on the haemagglutinating antibody response to sheep red blood cells (SRBC) in mice. Each point represents the mean titre, with $95 \%$ confidence limits, of 8-12 animals. Significant differences between control and test groups indicated by $p$ values. The shaded area represents the time during which serum C3 $<5 \%$ of normal in test animals; $\uparrow=$ intraperitoneal injection. Reprinted with permission from Macmillan Publishers Ltd. ${ }^{48}$

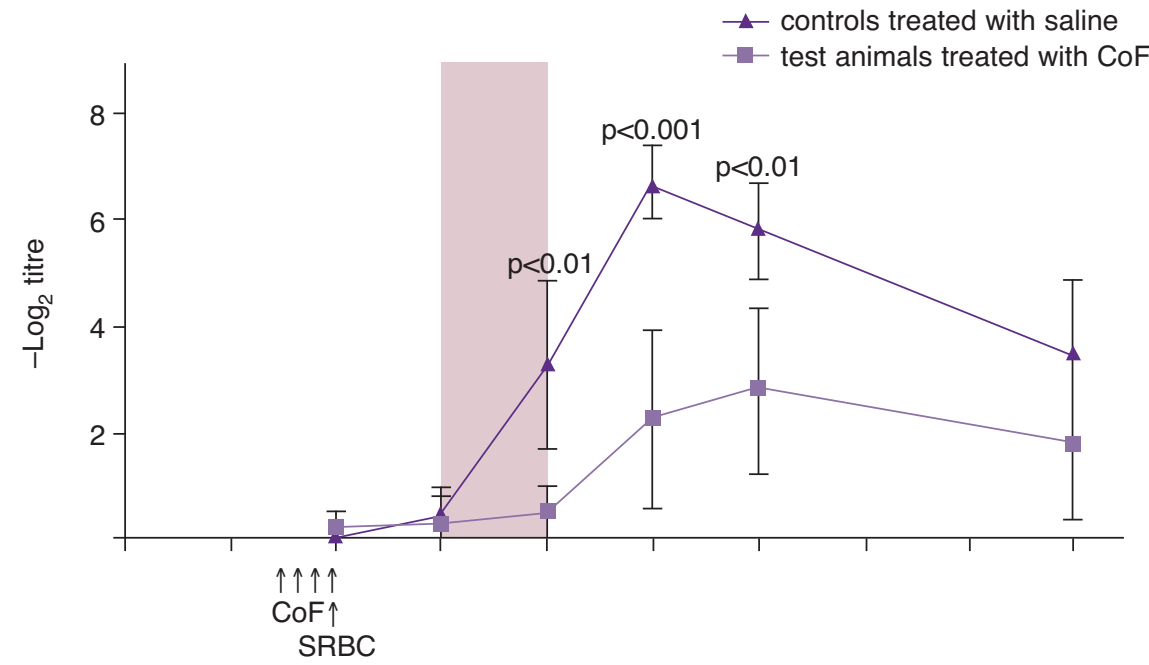

ited complement deficiencies and eventually in gene knockout mice. Attachment to antigens of the C3d fragment powerfully enhances the immune response, ${ }^{57}$ and current studies in this field potentially promise useful clinical applications derived from my original findings.

\section{C-reactive protein}

After completion of my $\mathrm{PhD}$ I returned to clinical training at the Royal Postgraduate Medical School, Hammersmith Hospital, where Professor Chris Booth told me that studying the role of complement in induction of the immune response was 'too basic' and that I should do something of greater clinical relevance: 'Why don't you crack Crohn's disease?'. Soon afterwards, in 1975, a paper appeared in the Journal of Experimental Medicine entitled 'Effects of C-reactive protein on the lymphoid system. Binding to thymus-dependent lymphocytes and alteration of their functions ${ }^{58}$ reporting that CRP inhibited the activation of $\mathrm{T}$ cells by antigens but not by mitogens. This seemed highly relevant to Crohn's disease in which suppression of T cell numbers and activity had then lately been reported. CRP concentrations had not previously been measured in Crohn's, so I started by preparing my own anti-CRP antiserum which required pure CRP as antigen. There were many different published methods for isolation of CRP, a sure sign that none of them was ideal, and I therefore devised some novel approaches and eventually immunised a rabbit with what I believed to be pure CRP. The animal produced excellent antibodies to CRP but also antibodies against another normal human serum protein. My pure CRP was evidently, and very serendipitously, contaminated. The contaminating protein was present at low and rather constant concentration in all sera but I was unable to identify it. We designated it protein $\mathrm{X}$ and just ignored it for a couple of years while using the antiserum to measure serum CRP values in patients with inflammatory bowel disease and many other conditions. C-reactive protein concentrations were notably raised in patients with active Crohn's and correlated very well with other indices of disease activity but, surprisingly, were usually only increased very modestly if at all in patients with even very active ulcerative colitis. ${ }^{59}$ This significant and still unexplained difference stimulated my enduring interest in clinical measurement of CRP and other acute proteins in different diseases. Our many clinical studies of CRP and production of the WHO International Reference Standard for CRP Immunoassay encouraged the now universal use of CRP assays in screening for organic disease, in monitoring disease activity and response to therapy, and for detection of intercurrent infection. ${ }^{5}$ In contrast to this positive outcome, my intensive investigations failed to confirm either that CRP bound to $\mathrm{T}$ cells or that it affected their functions, but serendipity had struck and the good had been done.

\section{Serum amyloid $\mathbf{P}$ component}

Subsequently, in seeking to optimise the isolation of CRP by calcium-dependent affinity chromatography on ligands immobilised on agarose beads, we surprisingly observed that protein X, the unidentified trace serum protein which had contaminated the original CRP antigen preparation, underwent specific calcium dependent binding to unsubstituted beaded agarose (Sepharose ${ }^{\circledR}$ ) and thus, remarkably, could be isolated in pure form from whole serum in a single pass. The good scientific practice of including an appropriate control had serendipitously yielded an unexpected benefit which was an irresistible stimulus to identify protein X. In the pre-proteomic era such identification was a considerable challenge but the late Arnold Feinstein, a brilliant immunochemist who was my colleague and mentor, suggested examination of isolated protein $\mathrm{X}$ by negative staining electron microscopy. The micrographs, produced by Ed Munn, revealed the unmistakeable morphology of serum amyloid P component (SAP) (Fig 3), a plasma protein which had been discovered in 1965 as a universal constituent of amyloid deposits, and exchange of reagents with other laboratories working on SAP swiftly confirmed its identity ${ }^{60}$ Discovery of the calcium-dependent ligand binding property of SAP provided the explanation for the presence of SAP in amyloid deposits, ${ }^{61}$ and our demonstration that SAP bound specifically to amyloid fibrils of all types opened the way to much 
Figure 3. Electron micrographs of negatively stained preparations of human serum amyloid $P$ component (a) and human C-reactive protein (b). Most molecules are seen face-on but arrows and inset (at higher magnification) show views of the disc-like molecules side-on. Original magnification, x320,000. Micrography performed by Dr EA Munn. Reprinted with permission from Elsevier. ${ }^{108}$
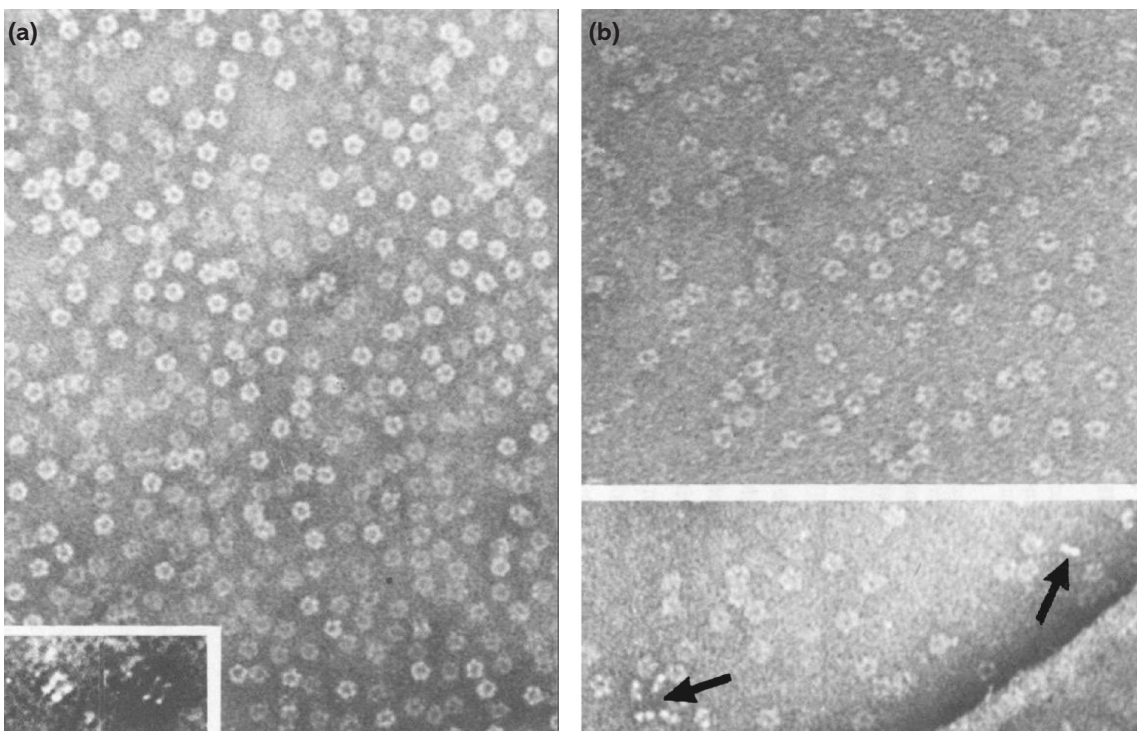

of our subsequent work on SAP and amyloidosis up to the present. Meanwhile, since SAP had co-isolated with CRP, we looked at pure CRP preparations in the electron microscope (Figure 3) and found that both proteins shared the same disc-like structure composed of five identical non-covalently associated subunits arranged with cyclic pentameric symmetry. Independently, Alex Osmand and Henry Gewurz found homologous N-terminal amino acid sequences in the two proteins and coined the name pentraxin, derived from the Greek penta (five) and ragos (berries), for this newly recognised family of plasma proteins. ${ }^{62}$

The existence of a CRP-like protein in rabbits had long been known, but in order to characterise the pentraxin family and to investigate the in vivo functions of these proteins, we deployed our optimised isolation procedures to study CRP and SAP in a wide variety of vertebrate species. ${ }^{63}$ In the process we eventually exhausted our original big batch of Sepharose beads and, much to our dismay, when we purchased a new lot there was dramatically less binding of SAP. While baffled by this problem, serendipity struck once more. Waiting at the security gatehouse to be admitted at Ciba-Geigy Ltd in Basel I got into conversation with another waiting visitor who introduced himself as Dr Don Renn of Pierce Chemical Company, Rockford, Illinois, a major commercial supplier of agarose. I immediately asked him about our problem and he turned out to be an authority on the chemistry of this polygalactan polysaccharide produced by seaweed. He informed me that agarose batches vary in their trace anionic constituents, sulphate and pyruvate, and subsequently sent us samples of different chemically characterised agaroses which enabled us to identify pyruvate as the specific ligand on agarose recognised by SAP. ${ }^{64}$ We synthesised the cyclic pyruvate acetal of galactose and showed that it specifically inhibited and reversed SAP binding. We then demonstrated the specific molecular dissociation of SAP from amyloid deposits and made the original suggestion that this could be a novel therapeutic approach to systemic and local forms of amyloidosis. ${ }^{65}$

\section{SAP scintigraphy and the National Amyloidosis Centre}

Recognition of the reversible nature of the interaction between SAP and amyloid fibrils also opened the way to our 1987 invention of radiolabelled SAP as a specific tracer for in vivo diagnosis and monitoring of amyloid deposits in patients, and its introduction into clinical practice. ${ }^{66-68}$ We have now performed over 10,000 SAP scintigraphy examinations and this absolutely specific, reproducible, completely safe and highly sensitive method has transformed our approach to management of systemic amyloidosis (Fig 4). One of the most important observations has been that amyloid deposits of all types can regress when the supply of amyloid fibril precursor proteins is sufficiently reduced. ${ }^{69}$ Availability of SAP scintigraphy triggered an ever-increasing number of referrals of amyloidosis patients and led to the establishment in 1999 of the UK NHS National Amyloidosis Centre at the Royal Free Hospital under the clinical directorship of Philip Hawkins. We now have the largest and most diverse collection of such cases anywhere in the world and have developed a multidisciplinary team with unique expertise in diagnosis and management of the disease. Better diagnosis and improved understanding of aetiology, pathogenesis, and response to treatment have yielded improved outcomes. Among 600 consecutive patients with systemic AL (monoclonal immunoglobulin light chain) amyloidosis evaluated at the National Amyloidosis Centre between 1990 and 2001, median survival increased from 1.9 years for the cohort diagnosed between 1990 and 1995 to 3.3 years for the cohort diagnosed between 1996 and 2001 ( $\mathrm{p}<0.0001)$. Since 1997, 132 patients with AL disease (20\%) survived more than five years, and 44 patients (12\%) survived more than 10 years. Among 204 patients treated with the medium intensity chemotherapy regime of vincristine, adriamycin and dexamethasone (VAD), median overall survival was 5.8 years for the whole cohort. Median survival was not reached at 12 years for the $21 \%$ of patients whose clonal disease responded completely, was 6.6 years for the $41 \%$ achieving a 

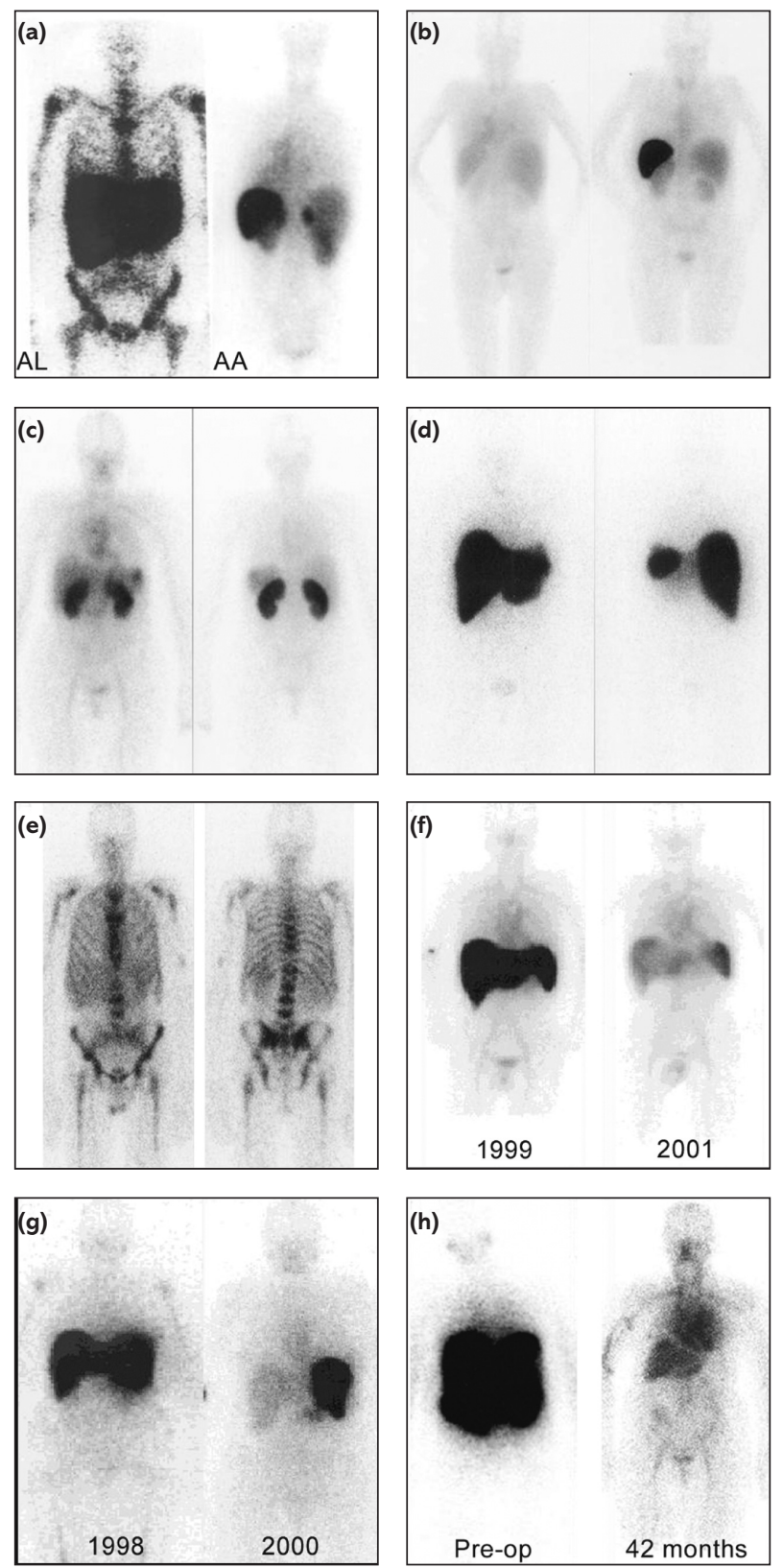

Figure 4. Whole body scintigraphy with ${ }^{123}$ l labelled serum amyloid $P$ component in systemic amyloidosis. (a) Anterior view of typical patient with $\mathrm{AL}$ amyloidosis showing massive liver and spleen amyloid and the pathognomonic deposits throughout the bone marrow that are not seen in any other type of amyloidosis (left). Posterior view of typical patient with AA amyloidosis showing amyloid in the spleen, kidneys and adrenal. The left adrenal is obscured by the overlying spleen but the right is clearly visible above the kidney (right). (b) Posterior scans taken a year apart in a patient with longstanding rheumatoid arthritis who suddenly developed AA amyloidosis. The earlier scan (left) is normal; the later one (right) shows heavy splenic and significant renal amyloidosis. (c) Anterior (left) and posterior (right) views of a patient with $\mathrm{AL}$ amyloid who presented with minor proteinuria and no other clinical or investigational evidence of disease. There is substantial renal amyloid but no scintigraphically detectable deposits elsewhere. (d) Anterior (left) and posterior (right) views of a different patient with $A L$ amyloid who also presented with minor proteinuria and no other clinical or investigational evidence of disease. There is massive amyloid deposition in the liver and spleen. The kidneys are not visualised probably because the tracer, which distributes according to the amount of amyloid, is all taken up elsewhere. Note that, in contrast to (c), there is no residual tracer in the circulation indicating a heavy whole body amyloid load and this patient would be unlikely to tolerate intensive chemotherapy. (e) Anterior (left) and posterior (right) views of a patient with $\mathrm{AL}$ amyloid who presented with multiple fractures over four years. X-ray and bone scan were normal but bone biopsy unexpectedly revealed amyloid. No monoclonal gammopathy was identifiable at that time but bone amyloid is frequent in $A L$ and may be the main clinical feature. (f) Serial anterior views showing regression of $A A$ amyloidosis in a juvenile rheumatoid arthritis patient treated with chlorambucil in whom the serum amyloid A concentration was suppressed to less than $10 \mathrm{mg} / \mathrm{l}$. (g) Serial anterior views showing regression of $\mathrm{AL}$ amyloidosis in a patient treated with high dose melphelan and stem cell rescue. (h) Serial anterior views of a 56-year-old woman who developed renal failure due to amyloidosis at age 33 . There was no family history and a diagnosis of $A L$ amyloidosis was made elsewhere by exclusion. She received two consecutive kidney transplants, each failing within five years. At age 51, massive hepatic amyloidosis caused end-stage liver failure (left) and she was referred to the National Amyloidosis Centre. The mutation encoding the amyloidogenic Glu526Val variant of fibrinogen A $\alpha$-chain was then identified and her amyloid shown by immunohistochemistry to be composed of fibrinogen. She received liver and kidney transplants and remains perfectly well with no sign of amyloidosis seven years later. Liver transplantation removes the source of the amyloidogenic variant fibrinogen and replaces it with normal wild type protein, thus curing the disease. In the 42 months postoperative scan (right) tracer is distributed only in the blood pool, showing up the heart, liver, major blood vessels and the transplanted kidney in the right iliac fossa. Reprinted with permission. Copyright (C) Annual Reviews 2007.69 partial response, and 1.9 years among non-responders $(\mathrm{p}<0.0001)$. This is the best survival reported in AL amyloidosis, exceeding the 4.7 year median survival described in more highly selected, and thus fitter, series of patients undergoing stem cell transplantation in the USA. In reactive systemic amyloid A (AA) amyloidosis, median survival from diagnosis has been 137 months among 374 patients at the National Amyloidosis Centre who were followed for a median of 86 months (2,673 patientyears), which is also notably better than previous historical series. These results exemplify the Ferrari metaphor which I enunciate overleaf.

The timing of development of SAP scintigraphy was extraordinarily serendipitous. From its inception in 1987 there has been a seamless translation from a blue skies, purely research activity, generously funded for 12 years by the MRC, into a rou-

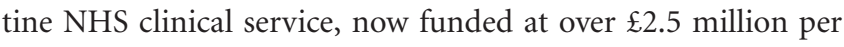
year by the Department of Health $(\mathrm{DH})$ via the National Commissioning Group of the DH. In stark and depressing contrast, if the idea of SAP scintigraphy had only arisen today, it would be absolutely impossible to even test it in patients let alone use it in routine clinical practice. The present inappropriate, excessive, bureaucratic and political overregulation of clinical research and innovation is an insuperable barrier, a perfect example of zemblanity.

\section{Medical training and the Ferrari metaphor}

Zemblanity is also now obvious in relation to medical training, exemplified by the Medical Training Application Service fiasco and the Modernising Medical Careers (MMC) disaster. That we 
Figure 5. (a) Two orthogonal views of the SAP-dAMP decamer. The two pentamers, shown in red and blue, respectively are related by a crystallographic dyad. The ligand, dAMP, is shown as a stick model and $\mathrm{Ca}$ ions are shown as small spheres. The decamer is viewed along the crystallographic twofold axis above and along the non-crystallographic fivefold axis below. (b) View of the contact region between serum amyloid $\mathrm{P}$ component pentamers. Reprinted with permission from Elsevier. ${ }^{75}$ (a)
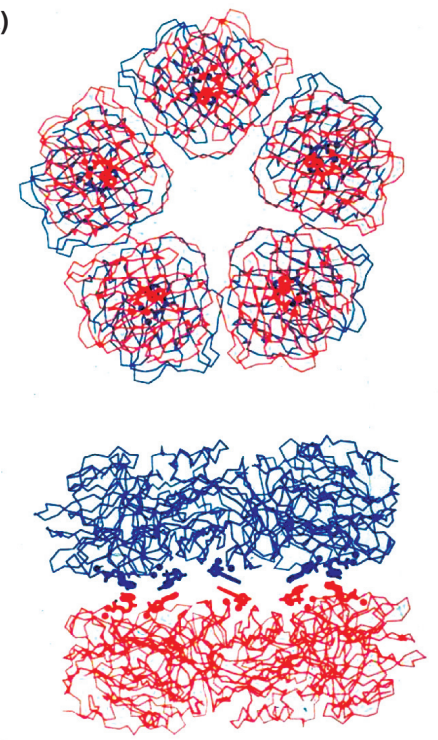

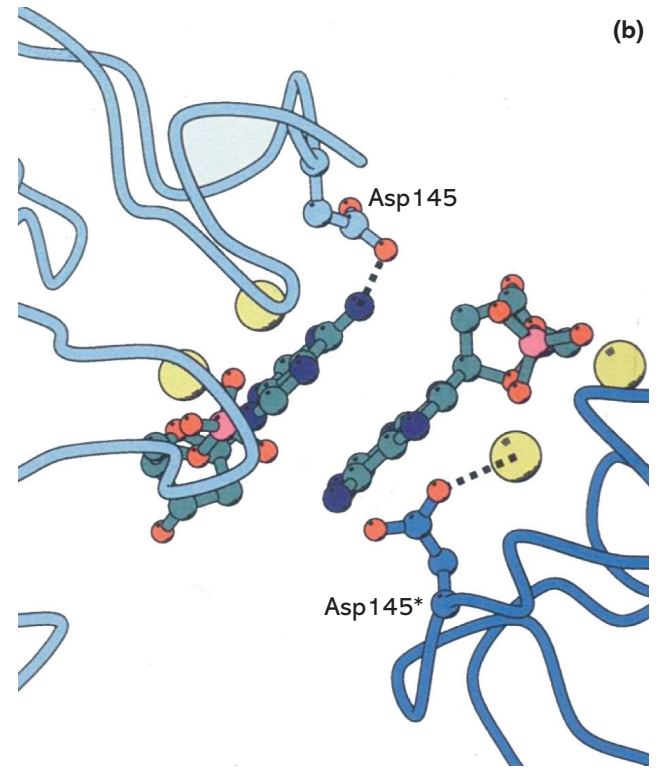

were able to train as professional clinicians and scientists, and translate our work into clinical practice, in a more favourable era is extremely serendipitous, and our patients are correspondingly fortunate. If $\mathrm{MMC}$ in its present form is not abandoned, the future of British biomedicine, sadly, will resemble the bleak landscape of Novaya Zemlya not the lush fertility of Serendip (Fig 1). If you were lucky enough to own a Ferrari, a superbly sophisticated and expensive piece of equipment, you would obviously have it maintained and repaired by a highly skilled Ferrari mechanic. You would not take your Ferrari to be repaired at Kwik-Fit. The patients whose care is our high calling, the continuation of excellence in all areas of clinical practice, and the creation of new developments in medicine, surely equally deserve the medical equivalent of Ferrari engineers. Properly educated, best-trained, and most highly motivated doctors can only be produced and validated by the medical profession, not by the government, by the $\mathrm{DH}$ or by their quangos.

\section{SAP as a therapeutic target}

The universality of SAP in amyloid deposits is intriguing. It may simply be incidental or it may reflect involvement of SAP in pathogenesis and/or persistence of amyloid deposits; in either case SAP could be a therapeutic target. Based on our evidence that SAP does contribute to pathogenesis of amyloidosis, ${ }^{70,71}$ we established a collaborative drug discovery programme with Roche, aiming to produce an inhibitor of SAP binding to amyloid fibrils in vivo capable of also dissociating bound SAP from the amyloid deposits. The interest of the pharmaceutical industry in this pro-
Figure 6. CPHPC and the structure of its complex with serum amyloid $P$ component (SAP). (a) Formula of CPHPC. (b) Two SAP pentamers crosslinked by means of their $B$ faces by five molecules of CPHPC (blue), viewed perpendicular to the fivefold axis. A face helices are shown in red. The two calcium ions bound to each SAP subunit are yellow. Reprinted with permission from Macmillan Publishers Ltd. ${ }^{76}$<smiles>O=C(O)[C@@H]1CCCN1C(=O)CCCCC(=O)N1CCC[C@H]1C(=O)O</smiles>

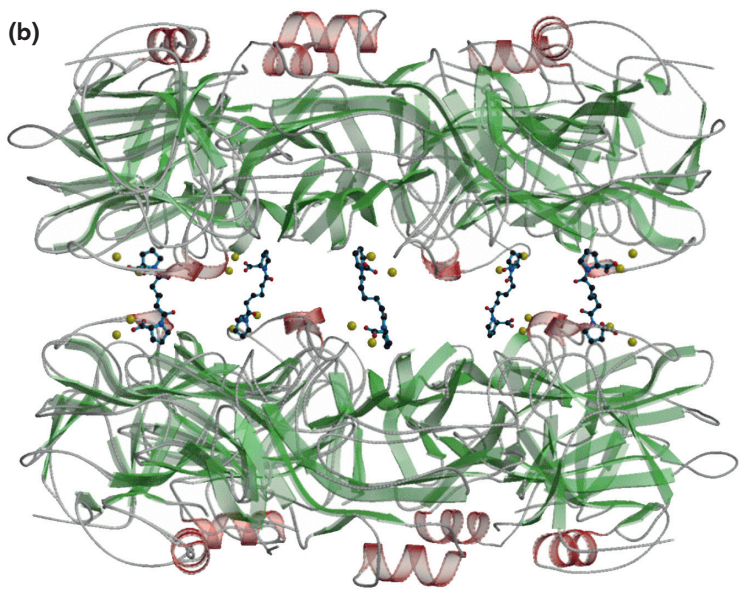
gramme centres on the fact that cerebral amyloid deposits are universal in Alzheimer's disease, which is the fourth most common cause of death in developed countries and a huge unmet medical need. It is a sad but inevitable example of zemblanity that, in the present hyper-regulated environment, the costs of drug development for relatively rare diseases, such as systemic amyloidosis, generally disqualify them as candidates, at least for big pharmaceutical companies.

My starting point for the SAP inhibitor drug programme was the serendipitous solution of the X-ray crystallographic structure of SAP. ${ }^{72-74}$ Despite intensive collaborative efforts from 1977 until 1999 we had been unable to crystallise CRP in a form suitable for X-ray analysis. In frustration we therefore eventually tried SAP instead and it immediately yielded robust crystals with 
Figure 7. Effect of CPHPC on circulating serum amyloid $\mathrm{P}$ component (SAP) values in patients with systemic amyloidosis. (a) Six patients with $\mathrm{AL}$ amyloidosis and one with $\mathrm{AA}$ type received doses of CPHPC between 0.25-6.0 mg per $\mathrm{kg}$ per day for $48 \mathrm{~h}$. The SAP concentration was measured immediately before and at the intervals shown during the infusion. Each point represents the mean (SD) of all patients. Reprinted with permission from Macmillan Publishers Ltd. ${ }^{76}$ (b) Concentration of SAP before and six weeks after starting treatment with CPHPC by subcutaneous injection at 0.15 to $1 \mathrm{mg} / \mathrm{kg} /$ day. Each point represents the SAP value in a single serum sample from each individual patient. Gillmore JD, Pepys $\mathrm{MB}$ et al, unpublished observations. (a)

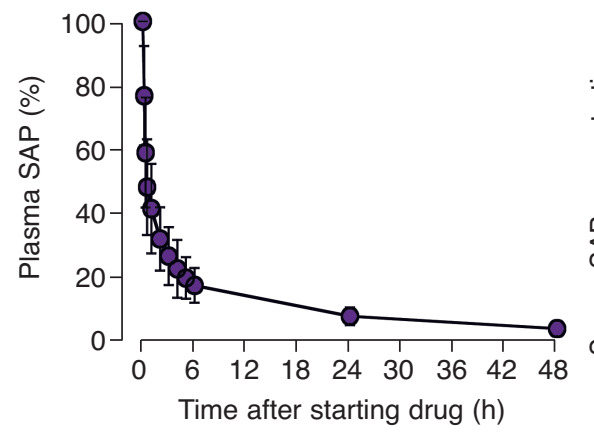

(b)

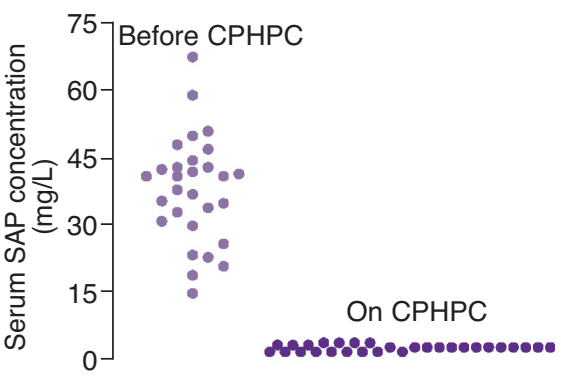

excellent diffraction. The 3D structure was solved in 1994 by Steve Wood and colleagues in the laboratory of Tom Blundell. ${ }^{72} \mathrm{I}$ had invented a high throughput screening assay for inhibitors of SAP binding to amyloid fibrils ${ }^{73,74}$ which Roche used to screen 100,000 compounds in their chemical compound library. The most attractive hit was one of the four diasteroisomers of captopril. Captopril itself and one of the other isomers were inactive but the fourth compound was apparently more active than the original hit. Only apparently because here again we experienced almost miraculous serendipity. These compounds all have a freesulphydryl group but oxidation had occurred during storage of the apparently more active compound, producing a disulphide cross-linked palindromic dimer which was actually the more potent substance. Erhard Hohenester, working with Steve Wood and myself, had then lately solved the X-ray crystal structure of a complex of SAP with the mononucleotide 2'-deoxyadenosine 5'monophosphate (dAMP), in which dAMP molecules bound in the ligand binding pocket on each of the protomers of individual pentameric SAP molecules produced cross-linking of pairs of SAP pentamers through hydrogen bonding between apposed mononucleotides (Fig 5). ${ }^{75}$ It was immediately obvious that comparable cross-linking of SAP molecules by a covalently joined pair of ligand head groups could explain the observed increased potency. This mechanism was confirmed by finding that a disulphide bridged palindromic version of the original hit compound was an even better inhibitor ligand for SAP. The subsequent medicinal chemistry programme, conducted by Roland Jakob-Roetne at Roche, yielded the drug which we have gone on to develop, (R)-1-[6-[(R)-2-Carboxy-pyrrolidin-1-yl]-6-oxo-hexanoyl] pyrrolidine-2-carboxylic acid (Fig 6). The palindromic acronym for the drug, CPHPC, designates the palindromic chemical structure, Carboxy Pyrrolidine Hexanoyl Pyrrolidine Carboxylic acid, which is essential for its pharmacological effect. ${ }^{76}$

Steve Wood's team solved the crystal structure of the complex between SAP and CPHPC (Fig 6) and showed that the multivalent binding of five palindromic drug molecules by two SAP molecules apposed face-to-face was indeed responsible for the tremendous gain in avidity underlying the greater potency of the compound as an inhibitor of SAP binding to amyloid fibrils. ${ }^{76}$ Rampant serendipity then continued unabated when we observed that administration of CPHPC to human subjects caused immediate and almost complete depletion of circulating SAP due to clearance of the SAP by the liver (Fig 7). ${ }^{76}$ Subsequently we have confirmed that the SAP-CPHPC complex formed in solution is recognised as abnormal by the liver and that this is the mechanism of SAP depletion. Targeted knockout of a potentially pathogenic circulating plasma protein by a specific palindromic or heterobifunctional small molecule drug is a novel pharmacological mechanism ${ }^{77,78}$ the principle of which is already being successfully applied by others to the design of drugs targeting cholera ${ }^{79}$ and shiga toxins, ${ }^{80}$ as well as by my own group for inhibition of $\mathrm{CRP}^{81}$ and other pathogenic proteins.

\section{C-reactive protein as a therapeutic target}

Why target CRP? Although measurement of this very sensitive but completely non-specific marker of inflammation and tissue damage is useful across much of clinical medicine, ${ }^{5}$ its baseline values are not helpful for assessment of cardiovascular disease
Figure 8. Effect of human C-reactive protein (CRP) on myocardial ischaemia/reperfusion injury in rats. Rats underwent 40-min coronary artery ischaemia followed by reperfusion and were then treated daily for five days with either vehicle alone $(n=9)$ or human CRP $(n=10)$, before measurement of (a) ejection fraction and (b) infarct size. Sharif I, Gray GA, Pepys MB et al, unpublished observations.
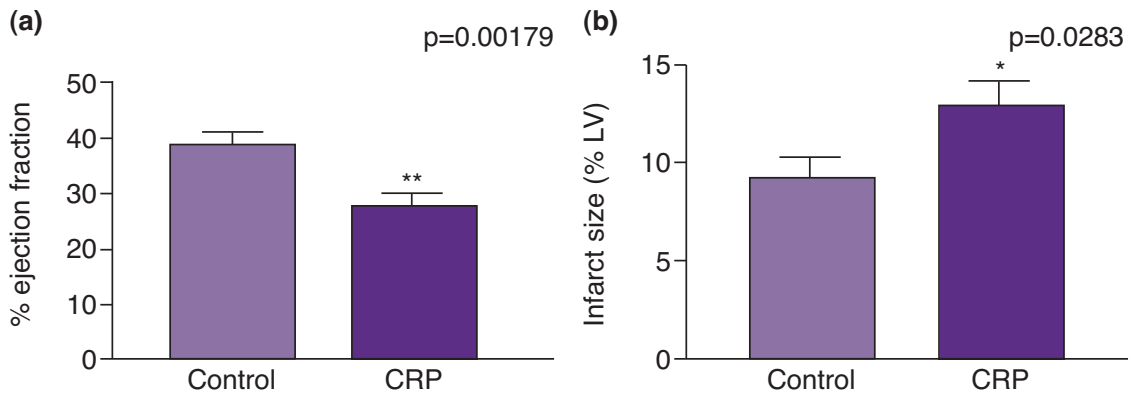
risk, ${ }^{13}$ nor is there any compelling evidence that CRP contributes to the pathogenesis of atherosclerosis. ${ }^{18}$ The idea that CRP might be involved in atherosclerosis started when we discovered the specific binding of CRP to low density and very low density lipoproteins in $1982^{82}$ but was brought to prominence by the infamous association-causality conflation and then enhanced by a perfect

Figure 9. 1,6-bis(phosphocholine)-hexane (bis(PC)-H) and structure of its complex with C-reactive protein. (a) Formula of bis(PC)-H. (b) Two CRP pentamers viewed down the fivefold axis, one in red and one in blue, crosslinked via their $B$ faces by five molecules of bis(PC)-H (green). (c) View of the complex perpendicular to the fivefold axis and along the local twofold axis, relating pairs of subunits. A face helices are in pink. Both views show the rotation of pentamers relative to each other, with corresponding displacement of Ca ions (yellow) and inclination of the drug molecules. Reprinted with permission from Macmillan Publishers Ltd. ${ }^{81}$

(a)<smiles>C[N+](=O)CCOP(=O)([O-])OCCCCCCOP(=O)([O-])OCC[N+](=O)[O-]</smiles>

(b)
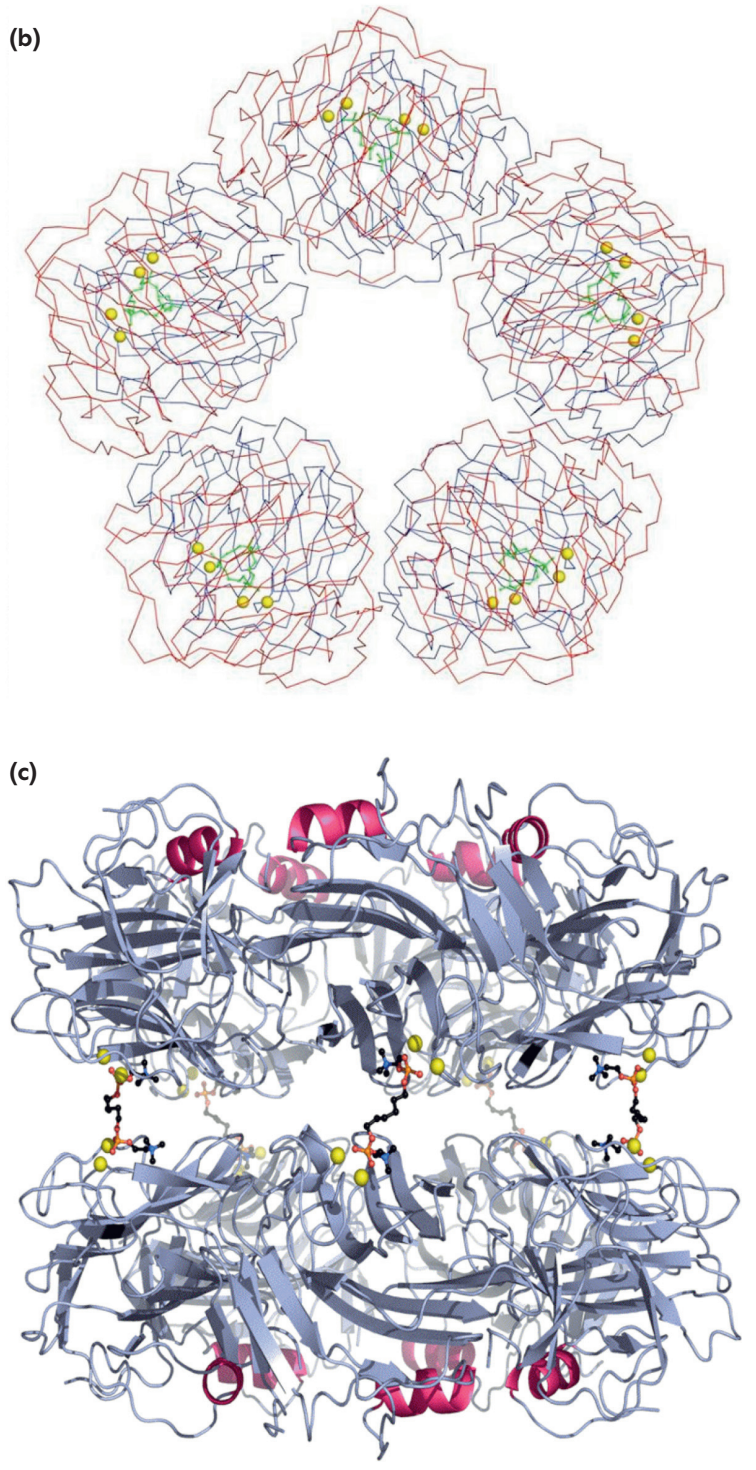

example of zemblanity, 'making expected bad discoveries by design'. Commercial protein preparations intended for in vitro immunochemical use are routinely shipped with sodium azide, a potently toxic bacteriostatic compound, added to prevent bacterial growth. Furthermore, proteins expressed by recombinant bacteria are inevitably contaminated with bacterial lipopolysaccharide (endotoxin), and potentially other bioactive bacterial products, unless extraordinary measures are taken to avoid this, as in pharmaceutical production. Commercial CRP preparations containing sodium azide and endotoxin definitely produce a variety of stimulatory and toxic effects on cells in culture, which in the absence of appropriate controls were wrongly ascribed to CRP. ${ }^{18,20}$ These effects are not produced by authentic pure human CRP itself. ${ }^{19,20}$ Indeed in vivo experimental animal work indicates that CRP is not pro-inflammatory ${ }^{16,83,84}$ and either has no effect on atherosclerosis ${ }^{16,84-86}$ or is actually atheroprotective. ${ }^{83}$

In marked contrast we have demonstrated in experimental models of $\mathrm{AMI}^{15}$ (Fig 8) and stroke ${ }^{14}$ that high concentrations of human CRP bind to dead and damaged cells in vivo and, by activating the complement system, lead to increased inflammation and exacerbation of injury. There are many clinical and pathological observations consistent with operation of this same mechanism in human AMI, ${ }^{87-95}$ and it is also likely to contribute to tissue damage in many other conditions, for example, rheumatoid arthritis ${ }^{96,97}$ or sepsis ${ }^{98}$ as well as stroke and other forms of ischaemic necrosis. However, the pathogenic effect of abundant acute phase concentrations of CRP must be clearly distinguished from the unsubstantiated claims for pro-inflammatory effects of modest increases in baseline CRP values.

In 1999 I accidentally and serendipitously observed that isolated pure CRP rapidly but reversibly precipitated when concentrated to about $50 \mathrm{mg} / \mathrm{ml}$. Use of such highly concentrated solutions enabled Darren Thompson and Steve Wood to produce X-ray diffracting crystals and finally to solve the physiological 3D structures of CRP itself and of CRP complexed with phosphocholine, its best ligand. ${ }^{99}$ Based on these structures and the palindromic drug principle ${ }^{76-78}$ we were then able to design de novo a potent inhibitor of CRP binding, 1,6 bis[\{[(trimethylammonium) ethoxy]phosphinyl\}-oxy] hexane (bis(PC)-H) (Fig 9), and showed in rat models of AMI and ischaemia/reperfusion injury that it completely abrogates the adverse effects of CRP in vivo (Fig 10). ${ }^{81}$ Our goal is now to optimise such drugs and expedite clinical testing in the hope that this approach will provide significant cardioprotection in acute coronary syndrome and after AMI, confer neuroprotection after stroke, and potentially reduce tissue damage after trauma as well as in a wide range of infective and inflammatory diseases.

\section{Treatment of amyloidosis}

Systemic amyloidosis is responsible for about one per 1,000 of all deaths in developed countries. It is extremely difficult to establish a drug development programme for such a relatively small market. An approach which eliminates the cerebral amyloid deposits of Alzheimer's disease and/or the islet amyloid deposits of type 2 diabetes would be much more attractive to the 
pharmaceutical industry. Unlike systemic amyloidosis, in which the amyloid deposits are unequivocally the cause of tissue damage and disease, it is not known whether cerebral and islet amyloid deposits cause dementia and diabetes respectively, whether they exacerbate these conditions or are just clinically silent epiphenomena. ${ }^{69} \mathrm{~A}$ treatment which cleared cerebral and islet deposits would thus be very informative even if it were not therapeutic.

Unfortunately, CPHPC is an insufficiently high affinity ligand to dissociate all the SAP from the deposits and has not thus far produced regression of systemic amyloid deposits, perhaps because the residual SAP may be sufficient to prevent amyloid regression. Nevertheless neither CPHPC itself nor sustained depletion of circulating SAP have caused any adverse effects in over 40 patient-years of exposure, and there is promising preliminary evidence of benefit. In particular, there may be preservation of renal function (Table 1) and possibly prolonged renal survival in some patients who have received CPHPC in the initial open label clinical study, suggesting that SAP depletion might retard new amyloid deposition. An adequately powered double blind placebo controlled clinical trial is now required to determine rigorously whether CPHPC is a useful treatment, but the expense and difficulty of conducting such a study are daunting for this rare and heterogeneous disease.

\section{Treatment of Alzheimer's disease?}

A trial in Alzheimer's disease would also be of interest since SAP is present in the cerebral amyloid deposits. SAP is synthesised in the liver and reaches the brain from the blood, and we therefore hypothesised that depletion of circulating SAP by parenteral CPHPC should clear SAP from the CSF and the brain. In a preliminary study of five patients with Alzheimer's disease conducted in collaboration with Martin Rossor we have recently confirmed this effect, and also shown that CPHPC itself enters

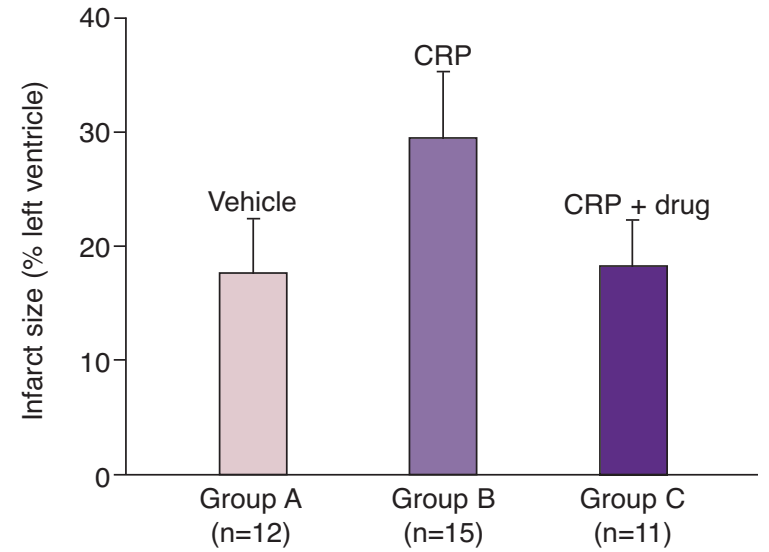

Figure 10. Abrogation by bis(PC)-H of the adverse effect of human C-reactive protein (CRP) on myocardial infarction in rats. Rats underwent terminal coronary artery occlusion and were then treated daily for five days with vehicle alone, human CRP alone, or human CRP plus bis(PC)-H infusion before measurement of infarct size. There was one death among 13 rats in group $A$, six among 21 in group $B$ but none of 11 in group C. Another control group received only drug; results, not shown, were not different from vehicle only group A. Significance of differences: A $v B, p=0.0001 ; A v C$, $\mathrm{p}=0.32 ; \mathrm{B} v \mathrm{C}, \mathrm{p}=0.0002$. Reprinted with permission from Macmillan Publishers Ltd. ${ }^{81}$

the CSF so that it is available to block any SAP which might be produced locally (Fig 11). In addition to the possibility that SAP depletion might promote the resolution of amyloid deposits, there are reports that SAP itself may be neurocytotoxic ${ }^{100-102}$ and thereby contribute directly to neurodegeneration in Alzheimer's disease, in which case SAP blockade and/or clearance would be desirable per se, unrelated to possible effects on amyloid deposits. The risks and costs of the phase $2 / 3$ clinical study needed to demonstrate efficacy of CPHPC in Alzheimer's disease are very high and thus present a challenging decision for the pharmaceutical industry. Watch this space.

Table 1. Effect of CPHPC on proteinuria in patients with hereditary systemic fibrinogen A $\alpha$-chain (AFib) amyloidosis.

\begin{tabular}{|c|c|c|c|}
\hline & $\begin{array}{c}\text { AFib patients } \\
\text { on CPHPC } \\
\text { (n=5) median } \\
\text { (range) }\end{array}$ & $\begin{array}{l}\text { Matched AFib } \\
\text { patients not on } \\
\text { CPHPC ( } n=5) \\
\text { median (range) }\end{array}$ & $\begin{array}{l}\text { Significance } \\
\text { (Mann-Whitney } \\
\text { U test) }\end{array}$ \\
\hline $\begin{array}{l}\text { Change in total proteinuria over } \\
52 \text { weeks }(\mathrm{g} / \mathrm{l})\end{array}$ & $\begin{array}{c}-0.37 \\
(-1.53-+0.20) \\
4 \text { decreased } \\
1 \text { increased }\end{array}$ & $\begin{array}{c}+1.43 \\
(-1.56-2.01) \\
1 \text { decreased, } \\
4 \text { increased }\end{array}$ & Not significant \\
\hline $\begin{array}{l}\text { Change in urine protein/creatinine } \\
\text { ratio over } 52 \text { weeks }(\mathrm{mg} / \mathrm{mmol})\end{array}$ & $\begin{array}{c}-92 \\
(-245-+108)\end{array}$ & $\begin{array}{c}+222 \\
(+169-+428)\end{array}$ & $p=0.008$ \\
\hline $\begin{array}{l}\text { Rate of change in proteinuria over } \\
\text { whole CPHPC treatment or observation } \\
\text { period (g/l/year) (range in weeks) }\end{array}$ & $\begin{array}{c}-0.14 \\
(-0.4-+0.2) \\
(34-257)\end{array}$ & $\begin{array}{c}+0.37 \\
(-0.09-+1.98) \\
(63-136)\end{array}$ & $p=0.032$ \\
\hline \multicolumn{4}{|c|}{$\begin{array}{l}\text { Note: Hereditary AFib amyloidosis has a rather uniform phenotype in which renal amyloidosis always predominates, presenting with proteinuria and } \\
\text { progressing inexorably to end-stage renal failure. The patients receiving CPHPC and the untreated controls were very closely matched for age, sex, } \\
\text { baseline creatinine clearance, protein/creatinine ratio, blood pressure and treatment with angiotensin-converting enzyme inhibitors or angiotensin II } \\
\text { receptor antagonists. One of the CPHPC-treated patients underwent curative combined kidney and liver transplantation as curative therapy }{ }^{106,107} \text { and } \\
\text { therefore discontinued CPHPC after } 34 \text { weeks. Gilmore JD, Pepys MB et al, unpublished observations. }\end{array}$} \\
\hline
\end{tabular}


Figure 11. Concentrations of CPHPC (a) and serum amyloid P component (b) in the cerebrospinal fluid of individual patients with moderate Alzheimer's disease before (week 0 ), during and after (week 16) receiving treatment with CPHPC $60 \mathrm{mg}$ three times a day (tds) by subcutaneous (sc) injection for 12 weeks. Ridha B, Rossor MN, Pepys MB et al, unpublished observations.

(a)

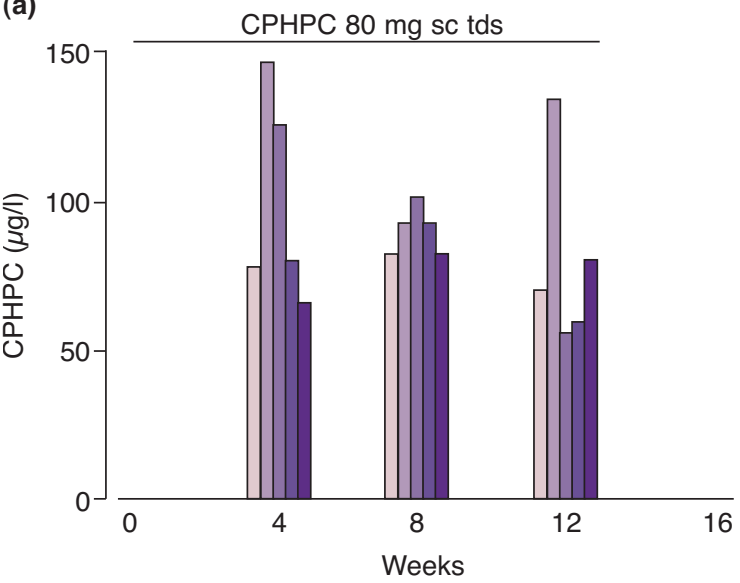

(b)

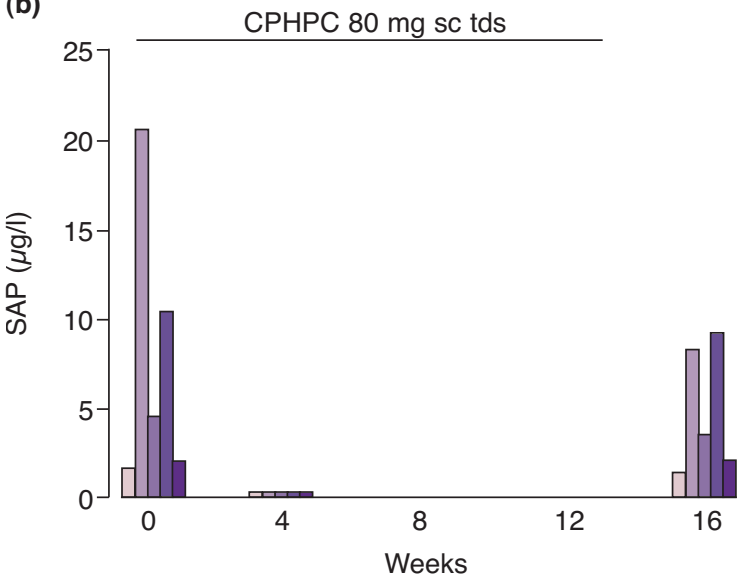

\section{Curing amyloidosis?}

Meanwhile what to do about the increasing numbers of patients with systemic amyloidosis, almost 1,000 of whom were seen in the National Amyloidosis Centre in 2006? We know that their amyloid deposits are responsible for their disease. ${ }^{69}$ These deposits consist predominantly of amyloid fibrils composed of aggregated misfolded precursor proteins, which differ in each type of amyloidosis, together with SAP bound to the fibrils. ${ }^{69}$ The use of SAP scintigraphy has enabled us to show that the treatments which reduce sufficiently the availability of the respective fibril precursor proteins, cause the deposits to regress. ${ }^{103-105}$ In each type of amyloidosis we therefore aim to deplete or abolish the supply of fibril precursor by whatever method is appropriate for the underlying disease, for example cytotoxic chemotherapy for AL amyloidosis, anti-inflammatory agents for AA amyloidosis and liver transplantation if the liver is the source of an amyloidogenic variant protein encoded by a mutant gene. ${ }^{69}$ Unfortunately it is often difficult or impossible to achieve our goal and the amyloidotic organ damage may be too advanced while amyloid regression is too slow. We need to be able to clear existing amyloid deposits from the affected organs swiftly and safely and now have promising evidence that this may be possible, based yet again on serendipity.

Administration of CPHPC to patients with systemic amyloidosis depletes almost all SAP from the blood and most but not all SAP from the amyloid deposits (Table 2). The residual SAP in the deposits remains accessible as a target for specific antibodies to SAP, and importantly the same will presumably apply to the amyloid deposits in Alzheimer's disease and type 2 diabetes. The mouse model of systemic AA amyloidosis, induced by chronic inflammation, very closely resembles the human disease with major deposits in the spleen and liver. Using human SAP transgenic mice, we have lately shown that the combination of CPHPC and a single dose of anti-human SAP antibodies produces safe and virtually complete disappearance of abundant

Table 2. Effect of CPHPC treatment on SAP content of amyloidotic spleens.

\begin{tabular}{|c|c|c|c|}
\hline Patient & Type of amyloid & $\begin{array}{c}\text { CPHPC mg per day } \\
\text { (weeks of treatment before death) }\end{array}$ & $\begin{array}{l}\text { SAP content mg per gram } \\
\text { estimated dry weight of amyloid }\end{array}$ \\
\hline 1 & AA & No CPHPC & 24 \\
\hline 2 & $\mathrm{AA}$ & No CPHPC & 16 \\
\hline 3 & $\begin{array}{l}\text { AApoAl } \\
\text { Leu60Arg }\end{array}$ & No CPHPC & 32 \\
\hline 4 & $\begin{array}{c}\text { ATTR } \\
\text { Ser52Pro }\end{array}$ & No CPHPC & 20 \\
\hline 5 & $\begin{array}{c}\text { AFib } \\
\text { Glu526Val }\end{array}$ & No CPHPC & 20 \\
\hline 6 & $\begin{array}{c}\text { AFib } \\
\text { Glu526Val }\end{array}$ & $80(41)$ & 2.0 \\
\hline 7 & $A L \lambda$ & $20(25)$ & 3.6 \\
\hline
\end{tabular}

$\mathrm{AA}=$ reactive systemic amyloidosis; AApoAlLeu60Arg = hereditary systemic apolipoprotein Al amyloidosis caused by Leu60Arg substitution; ATTRSer52Pro = hereditary systemic transthyretin amyloidosis caused by Ser52Pro substitution; AFibGlu526Val = hereditary systemic fibrinogen A a-chain amyloidosis caused by Glu526Val substitution; AL $\lambda=$ systemic monoclonal immunoglobulin I type light chain amyloidosis. Tennent GA, Pepys MB et al, unpublished observations. 
Figure 12. Clearance of systemic AA amyloidosis in human serum amyloid $P$ component (SAP) transgenic mice following treatment with CPHPC and anti-SAP antibody. All mice simultaneously underwent the same amyloid induction regime and were then divided into groups confirmed by ${ }^{125}$ SAP retention to have the same overall amyloid load. Each group then received the treatments shown and was examined 28 days later to determine residual amyloid load. Results are shown for the spleen with each symbol representing an individual animal. The semi-quantitative amyloid score is on a log scale. There was no detectable amyloid in most of the antibody-treated group, with just microscopic traces in a small proportion, whereas most of the mice in each of the control groups had abundant amyloid deposits. Kahan MC, Pepys MB et al, unpublished observations.

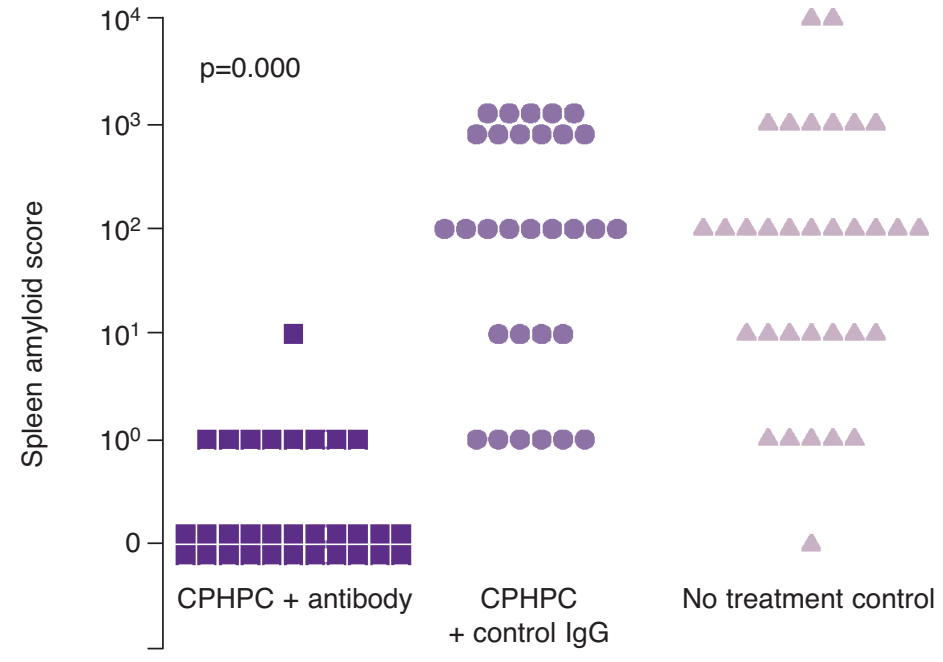

systemic amyloid deposits (Figs 12 and 13). Provided we can overcome the challenging regulatory and cost hurdles of drug development, our new approach should be transferable into patients. It should have the same effects in systemic amyloidosis patients as it does in the mouse model, and it should also yield important information about the role of the amyloid deposits in Alzheimer's disease and type 2 diabetes. Despite our best efforts and much improved outcomes, most patients with systemic amyloidosis still die of the disease, and Alzheimer's disease and type 2 diabetes remain areas of considerable unmet medical need, so there are compelling reasons to proceed.

Figure 13. Spleen sections from two of the mice from the experiment shown in Figure 12 stained with alkaline alcoholic Congo red and viewed in cross polarised light. (a) Strong pathognomonic green birefringence denoting massive amyloid deposition in the spleen of a control mouse with amyloid score $10^{4}$. (b) Spleen from a treated mouse showing just three residual specks of green birefringent amyloid (circled), amyloid score $10^{\circ}$. Kahan MC, Pepys MB et al, unpublished observations.
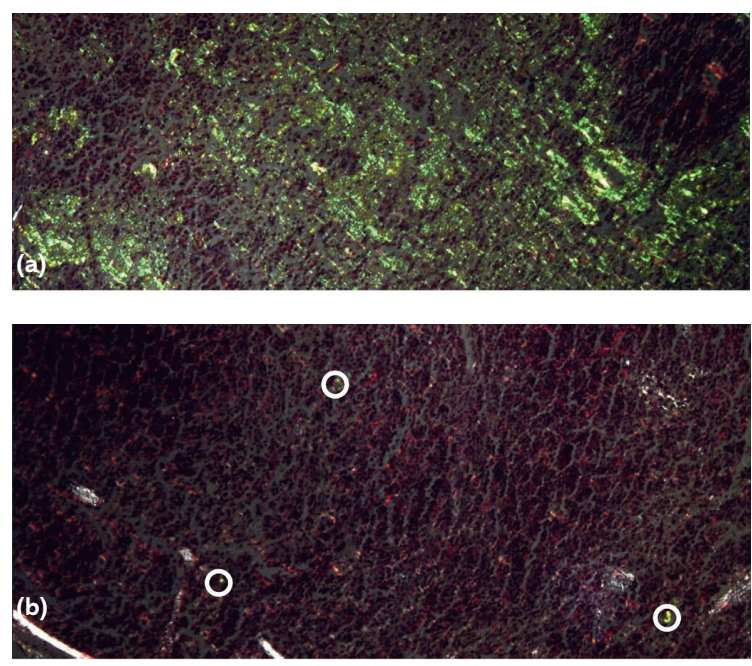

\section{Acknowledgements}

I am very grateful to the previous President, Dame Carol Black, and the Censors of the College for the privilege of being invited to give this oration. I also very sincerely acknowledge the wonderful collaboration of my many colleagues whose expertise and industry over the past 37 years have made possible the work mentioned in this oration. They are too numerous to mention individually but their names appear in the cited literature. Finally, it is a great pleasure to thank the MRC for continuous support since 1969, without which I would have had no personal science to report, the Wolfson Foundation for generous funding, and the Wellcome Trust whose recent substantial Seeding Drug Discovery Initiative award is now enabling us to vigorously explore other therapeutic avenues. Unfortunately drug development is slow as well as being enormously expensive, and since I very much wish to see the outcomes myself I feel compelled to echo Seinfeld, the well known American comedian, who said, 'I intend to live for ever - so far so good'.

\section{References}

1 Wilson EO. Consilience: the unity of knowledge. New York: Knopf, 1998.

2 Park R. Voodoo science: the road from foolishness to fraud. Oxford: Oxford University Press, 2001.

3 Feynman RP. Surely you're joking Mr Feynman! Adventures of a curious character. London: Vintage Books, 1985.

4 Tallis R. Longer, healthier, happier? Human needs, human values and science. The Sense about Science Lecture 2007. www.senseaboutscience.org.uk/index.php/site/project/127

5 Pepys MB, Hirschfield GM. C-reactive protein: a critical update. J Clin Invest 2003;111:1805-12.

6 Liuzzo G, Biasucci LM, Gallimore JR et al. The prognostic value of C-reactive protein and serum amyloid A protein in severe unstable angina. N Engl J Med 1994;331:417-24.

7 Thompson SG, Kienast J, Pyke SDM, Haverkate F, van de Loo JCW. Hemostatic factors and the risk of myocardial infarction or sudden death in patients with angina pectoris. N Engl J Med 1995;332:635-41.

8 Kuller LH, Tracy RP, Shaten J, Meilahn EN, for the MRFIT Research Group. Relation of C-reactive protein and coronary heart-disease in the MRFIT nested case control study. Am J Epidemiol 1996;144: 537-47. 
9 Ridker PM, Cushman M, Stampfer MJ, Tracy RP, Hennekens CH. Inflammation, aspirin, and the risk of cardiovascular disease in apparently healthy men. N Engl J Med 1997;336:973-9.

10 Ridker PM, Buring JE, Shih J, Matias M, Hennekens CH. Prospective study of C-reactive protein and the risk of future cardiovascular events among apparently healthy women. Circulation 1998;98:731-3.

11 Koenig W, Sund M, Fröhlich M et al. C-reactive protein, a sensitive marker of inflammation, predicts future risk of coronary heart disease in initially healthy middle-aged men: results from the MONICA (Monitoring Trends and Determinants in Cardiovascular Disease) Augsburg Cohort Study, 1984 to 1992. Circulation 1999;99:237-42.

12 Danesh J, Collins R, Appleby P, Peto R. Association of fibrinogen, C-reactive protein, albumin, or leukocyte count with coronary heart disease. JAMA 1998;279: 1477-82.

13 Lowe GDO, Pepys MB. C-reactive protein and cardiovascular disease: weighing the evidence. Curr Atheroscler Rep 2006;8:421-8.

14 Gill R, Kemp JA, Sabin C, Pepys MB. Human C-reactive protein increases cerebral infarct size after middle cerebral artery occlusion in adult rats. J Cereb Blood Flow Metab 2004;24:1214-8.

15 Griselli M, Herbert J, Hutchinson WL et al. C-reactive protein and complement are important mediators of tissue damage in acute myocardial infarction. J Exp Med 1999;190:1733-9.

16 Hirschfield GM, Gallimore JR, Kahan MC et al. Transgenic human $\mathrm{C}$-reactive protein is not proatherogenic in apolipoprotein E-deficient mice. Proc Natl Acad Sci USA 2005;102:8309-14.

17 Pepys MB, Nissen S. CRP is not proatherogenic, new animal study suggests. Heartwire. May 262005. www.theheart.org/viewArticle.do?primaryKey $=487235$

18 Pepys MB. CRP or not CRP? That is the question. Arterioscler Thromb Vasc Biol 2005;25:1091-4.

19 Pepys MB, Hawkins PN, Kahan MC et al. Proinflammatory effects of bacterial recombinant human $\mathrm{C}$-reactive protein are caused by contamination with bacterial products, not by C-reactive protein itself. Circ Res 2005;97:e97-103.

20 Taylor KE, Giddings JC, van den Berg CW. C-reactive protein-induced in vitro endothelial cell activation is an artefact caused by azide and lipopolysaccharide. Arterioscler Thromb Vasc Biol 2005;25:1225-30.

21 The Emerging Risk Factors Collaboration. The Emerging Risk Factors Collaboration: analysis of individual data on lipid, inflammatory and other markers in over 1.1 million participants in 104 prospective studies of cardiovascular diseases. Eur J Epidemiol (in press).

22 Tallis R. Right, what have the scientists ever done for us? Well.... The Times. 28 February 2007. www.timesonline.co.uk/tol/comment/ columnists/guest_contributors/article1449416.ece

23 Kidd IM, Booth CJ, Rigden SP, Tong CY, MacMahon EM. Measlesassociated encephalitis in children with renal transplants: a predictable effect of waning herd immunity? Lancet 2003;362:832.

24 Peltola H, Patja A, Leinikki P et al. No evidence for measles, mumps, and rubella vaccine-associated inflammatory bowel disease or autism in a 14-year prospective study. Lancet 1998;351:1327-8.

25 Patja A, Davidkin I, Kurki T et al. Serious adverse events after measlesmumps-rubella vaccination during a fourteen-year prospective followup. Pediatr Infect Dis J 2000;19:1127-34.

26 Gillberg C, Heijbel H. MMR and autism (comment). Autism 1998;2: 423-4.

27 Taylor B, Miller E, Farrington CP et al. Autism and measles, mumps, and rubella vaccine: no epidemiological evidence for a causal association. Lancet 1999;353: 2026-9.

28 Dales L, Hammer SJ, Smith NJ. Time trends in autism and in MMR immunization coverage in California. JAMA 2001;285:1183-5.

29 Kaye JA, del Mar Melero-Montes M, Jick H. Mumps, measles, and rubella vaccine and the incidence of autism recorded by general practitioners: a time trend analysis. BMJ 2001;322:460-3.

30 DeWilde S, Carey IM, Richards N, Hilton SR, Cook DG. Do children who become autistic consult more often after MMR vaccination? Br J Gen Pract 2001;51:226-7.

31 Fombonne E, Chakrabarti S. No evidence for a new variant of measles-mumps-rubella-induced autism. Pediatrics 2001;108:E58.

32 Black C, Kaye JA, Jick H. Relation of childhood gastrointestina disorders to autism: nested case-control study using data from the UK General Practice Research Database. BMJ 2002;325:419-21.

33 Madsen KM, Hviid A, Vestergaard M et al. A population-based study of measles, mumps, and rubella vaccination and autism. $N$ Engl J Med 2002;347:1477-82.

34 Taylor B, Miller E, Lingam R et al. Measles, mumps, and rubella vaccination and bowel problems or developmental regression in children with autism: population study. BMJ 2002;324:393-6.

35 DeStefano F, Karapurkar Bhasin T, Thompson WW, Yeargin-Allsopp $\mathrm{M}$, Boyle C. Age at first measles-mumps-rubella vaccination in children with autism and school-matched control subjects: A population-based study in metropolitan Atlanta. Pediatrics 2004; 113:259-66.

36 Smeeth L, Cook C, Fombonne E et al. MMR vaccination and pervasive developmental disorders: a case-control study. Lancet 2004; 364:963-9.

37 Honda H, Shimizu Y, Rutter M. No effect of MMR withdrawal on the incidence of autism: a total population study. J Child Psychol Psychiatry 2005;46:572-9.

38 Miller C, Andrews N, Rush M et al. The epidemiology of subacute sclerosing panencephalitis in England and Wales 1990-2002. Arch Dis Child 2004;89:1145-8.

39 Miller E, Andrews N, Grant A, Stowe J, Taylor B. No evidence of an association between MMR vaccine and gait disturbance. Arch Dis Child 2005;90:292-6.

40 Miller E, Andrews N, Waight P, Taylor B. Bacterial infections, immune overload, and MMR vaccine. Measles, mumps, and rubella. Arch Dis Child 2003;88:222-3.

41 Hviid A, Stellfeld M, Wohlfahrt J, Melbye M. Association between thimerosal-containing vaccine and autism. JAMA 2003;290:1763-6.

42 Madsen KM, Lauritsen MB, Pedersen CB et al. Thimerosal and the occurrence of autism: negative ecological evidence from Danish population-based data. Pediatrics 2003;112:604-6.

43 Verstraeten T, Davis RL, DeStefano F et al. Safety of thimerosalcontaining vaccines: a two-phased study of computerized health maintenance organization databases. Pediatrics 2003;112:1039-48.

44 Andrews N, Miller E, Grant A et al. Thimerosal exposure in infants and developmental disorders: a retrospective cohort study in the United Kingdom does not support a causal association. Pediatrics 2004;114:584-91.

45 Heron J, Golding J, and the ALSPAC Study Team. Thimerosal exposure in infants and developmental disorders: a prospective cohort study in the United Kingdom does not support a causal association. Pediatrics 2004;114:577-83.

46 Boyd W. Armadillo. London: Hamish Hamilton, 1998.

47 Sommer TJ. Suppression of scientific research: bahramdipity and nulltiple scientific discoveries. Sci Eng Ethics 2001;7:77-104.

48 Pepys MB. Role of complement in induction of the allergic response. Nature New Biol 1972;237:157-9.

49 Feldmann M, Pepys MB. Role of C3 in in vitro lymphocyte cooperation. Nature 1974;249:159-61.

50 Pepys MB. Role of complement in induction of antibody production in vivo. Effect of cobra factor and other C3-reactive agents on thymusdependent and thymus-independent antibody responses. J Exp Med 1974;140:126-45.

51 Pepys MB. Complement-mediated mixed aggregation of murine spleen cells. Nature 1974;249:51-3.

52 Pepys MB, Butterworth AE. Inhibition by C3 fragments of C3-dependent rosette formation and antigen induced lymphocyte transformation. Clin Exp Immunol 1974;18:272-82.

53 Papamichail M, Gutierrez C, Embling P et al. Complement dependence of localisation of aggregated IgG in germinal centres. Scand J Immunol 1975;4:343-7.

54 Pepys MB. Role of complement in the induction of immunological responses. Transplant Rev 1976;32:93-120. 
55 Pepys MB, Wansbrough-Jones MH, Mirjah DD. Suppression of IgA antibody produced by in vivo complement depletion. Clin Exp Immunol 1976;23:378-81.

56 Pepys MB, Brighton WD, Hewitt BE, Bryant DEW, Pepys J. Complement in the induction of IgE antibody formation. Clin Exp Immunol 1977;27:397-400.

57 Fearon DT. The complement system and adaptive immunity. Semin Immunol 1998;10:355-61.

58 Mortensen RF, Osmand AP, Gewurz H. Effects of C-reactive protein on the lymphoid system I. Binding to thymus-dependent lymphocytes and alteration of their functions. J Exp Med 1975;141:821-39.

59 Pepys MB, Druguet M, Klass HJ et al. Immunological studies in inflammatory bowel disease. In: Knight J, Porter R (eds). Immunology of the gut. Ciba Foundation Symposium 46. Amsterdam: Elsevier/Excerpta Medica/North Holland, 1977:283-97.

60 Pepys MB, Dash AC, Munn EA et al. Isolation of amyloid P component (protein AP) from normal serum as a calcium-dependent binding protein. Lancet 1977;i:1029-31.

61 Pepys MB, Dyck RF, de Beer FC, Skinner M, Cohen AS. Binding of serum amyloid P component (SAP) by amyloid fibrils. Clin Exp Immunol 1979;38:284-93.

62 Osmand AP, Friedenson B, Gewurz $\mathrm{H}$ et al. Characterisation of $\mathrm{C}$-reactive protein and the complement subcomponent $\mathrm{Clt}$ as homologous proteins displaying cyclic pentameric symmetry (pentraxins). Proc Natl Acad Sci USA 1977;74:739-43.

63 Pepys MB, Dash AC, Fletcher TC et al. Analogues in other mammals and in fish of human plasma proteins C-reactive protein and amyloid P component. Nature 1978;273:168-70.

64 Hind CRK, Collins PM, Renn D et al. Binding specificity of serum amyloid P component for the pyruvate acetal of galactose. J Exp Med 1984;159:1058-69.

65 Hind CRK, Collins PM, Caspi D, Baltz ML, Pepys MB. Specific chemical dissociation of fibrillar and non-fibrillar components of amyloid deposits. Lancet 1984;ii:376-8.

66 Hawkins PN, Myers MJ, Lavender JP, Pepys MB. Diagnostic radionuclide imaging of amyloid: biological targeting by circulating human serum amyloid P component. Lancet 1988;i:1413-8.

67 Hawkins PN, Lavender JP, Pepys MB. Evaluation of systemic amyloidosis by scintigraphy with ${ }^{123}$ I-labeled serum amyloid $\mathrm{P}$ component. N Engl J Med 1990;323:508-13.

68 Hawkins PN, Wootton R, Pepys MB. Metabolic studies of radioiodinated serum amyloid $\mathrm{P}$ component in normal subjects and patients with systemic amyloidosis. J Clin Invest 1990;86:1862-9.

69 Pepys MB. Amyloidosis. Annu Rev Med 2006;57:223-41.

70 Botto M, Hawkins PN, Bickerstaff MCM et al. Amyloid deposition is delayed in mice with targeted deletion of the serum amyloid $\mathrm{P}$ component gene. Nature Med 1997;3:855-9.

71 Tennent GA, Lovat LB, Pepys MB. Serum amyloid P component prevents proteolysis of the amyloid fibrils of Alzheimer's disease and systemic amyloidosis. Proc Natl Acad Sci USA 1995;92:4299-303.

72 Emsley J, White HE, O'Hara BP et al. Structure of pentameric human serum amyloid P component. Nature 1994;367:338-45.

73 Pepys MB, Blundell TL. Screening assays to identify therapeutic agents for amyloidosis. US patent 6126918 (3 October 2000).

74 Pepys MB, Blundell TL. Therapeutic and diagnostic agents for amyloidosis, European patent EP0714405 (pending).

75 Hohenester E, Hutchinson WL, Pepys MB, Wood SP. Crystal structure of a decameric complex of human serum amyloid P component with bound dAMP. J Mol Biol 1997;269:570-8.

76 Pepys MB, Herbert J, Hutchinson WL et al. Targeted pharmacological depletion of serum amyloid $\mathrm{P}$ component for treatment of human amyloidosis. Nature 2002;417:254-9.

77 Pepys MB. Therapeutic agent. US patent 7,045,499 B2 (16 May 2006).

78 Pepys MB. Therapeutic agent for depletion of an unwanted protein population from plasma. European patent 1418905 (2 May 2007).

79 Liu J, Zhang Z, Tan X et al. Protein heterodimerization through ligand-bridged multivalent pre-organization: enhancing ligand binding toward both protein targets. J Am Chem Soc 2005;127:2044-5.

80 Solomon D, Kitov PI, Paszkiewicz E et al. Heterobifunctional multivalent inhibitor-adaptor mediates specific aggregation between Shiga toxin and a pentraxin. Org Lett 2005;7:4369-72.

81 Pepys MB, Hirschfield GM, Tennent GA et al. Targeting C-reactive protein for the treatment of cardiovascular disease. Nature 2006;440: 1217-21.

82 de Beer FC, Soutar AK, Baltz ML et al. Low density and very low density lipoproteins are selectively bound by aggregated C-reactive protein. J Exp Med 1982;156:230-42.

83 Kovacs A, Tornvall P, Nilsson R et al. Human C-reactive protein slows atherosclerosis development in a mouse model with human-like hypercholesterolemia. Proc Natl Acad Sci USA 2007;104:13768-73.

84 Tennent GA, Hutchinson WL, Kahan MC et al. Transgenic human CRP is not pro-atherogenic, pro-atherothrombotic or proinflammatory in apoE $\mathrm{E}^{-/-}$mice. Atherosclerosis. Epub ahead of print: doi:10.1016/j.atherosclerosis. 2007.05.010.

85 Reifenberg K, Lehr H-A, Baskal D et al. Role of C-reactive protein in atherogenesis: can the apolipoprotein $\mathrm{E}$ knockout mouse provide the answer? Arterioscler Thromb Vasc Biol 2005;25:1641-6.

86 Trion A, de Maat MPM, Jukema JW et al. No effect of C-reactive protein on early atherosclerosis development in apolipoprotein $\mathrm{E}^{\star} 3$ Leiden/human C-reactive protein transgenic mice. Arterioscler Thromb Vasc Biol 2005;25:1635-40.

87 Pietilä KO, Harmoinen AP, Jokiniitty J, Pasternack AI. Serum C-reactive protein concentration in acute myocardial infarction and its relationship to mortality during 24 months of follow-up in patients under thrombolytic treatment. Eur Heart J 1996;17:1345-9.

88 Ueda S, Ikeda U, Yamamoto $\mathrm{K}$ et al. C-reactive protein as a predictor of cardiac rupture after acute myocardial infarction. Am Heart J 1996; 131:857-60.

89 Lagrand WK, Niessen HWM, Wolbink G-J et al. C-reactive protein colocalizes with complement in human hearts during acute myocardial infarction. Circulation 1997;95:97-103.

90 Nijmeijer R, Lagrand WK, Visser CA et al. CRP, a major culprit in complement-mediated tissue damage in acute myocardial infarction? Int Immunopharmacol 2001;1:403-14.

91 Nijmeijer R, Lagrand WK, Lubbers YTP et al. C-reactive protein activates complement in infarcted human myocardium. Am J Pathol 2003;163:269-75.

92 Nijmeijer R, Krijnen PAJ, Assink J et al. C-reactive protein and complement depositions in human infarcted myocardium are more extensive in patients with reinfarction or upon treatment with reperfusion. Eur J Clin Invest 2004;34:803-10.

93 Kinjo K, Sato H, Ohnishi Y et al. Impact of high-sensitivity C-reactive protein on predicting long-term mortality of acute myocardial infarction. Am J Cardiol 2003;91:931-5.

94 Suleiman M, Aronson D, Reisner SA et al. Admission C-reactive protein levels and 30-day mortality in patients with acute myocardial infarction. Am J Med 2003;115:695-701.

95 Suleiman M, Khatib R, Agmon Y et al. Early inflammation and risk of long-term development of heart failure and mortality in survivors of acute myocardial infarction predictive role of C-reactive protein. J Am Coll Cardiol 2006;47:962-8.

96 Gitlin JD, Gitlin JI, Gitlin D. Localisation of C-reactive protein in synovium of patients with rheumatoid arthritis. Arthritis Rheum 1977;20:1491-9.

97 Molenaar ET, Voskuyl AE, Familian A et al. Complement activation in patients with rheumatoid arthritis mediated in part by C-reactive protein. Arthritis Rheum 2001;44:997-1002.

98 Wolbink G-J, Bossink AWJ, Groeneveld ABJ et al. Complement activation in patients with sepsis is in part mediated by C-reactive protein. J Infect Dis 1998; 177:81-7.

99 Thompson D, Pepys MB, Wood SP. The physiological structure of human C-reactive protein and its complex with phosphocholine. Structure 1999;7:169-77.

100 Urbányi Z, Lakics V, Erdó SL. Serum amyloid P component-induced 
cell death in primary cultures of rat cerebral cortex. Eur J Pharmacol 1994;270:375-87.

101 Urbányi Z, Laszlo L, Tomasi TB et al. Serum amyloid P component induces neuronal apoptosis and beta-amyloid immunoreactivity. Brain Res 2003;988:69-77.

102 Urbányi Z, Sass M, Laszy J et al. Serum amyloid P component induces TUNEL-positive nuclei in rat brain after intrahippocampal administration. Brain Res 2007;1145:221-6.

103 Gillmore JD, Lovat LB, Persey MR, Pepys MB, Hawkins PN. Amyloid load and clinical outcome in AA amyloidosis in relation to circulating concentration of serum amyloid A protein. Lancet 2001;358:24-9.

104 Lachmann HJ, Gallimore R, Gillmore JD et al. Outcome in systemic $\mathrm{AL}$ amyloidosis in relation to changes in concentration of circulating free immunoglobulin light chains following chemotherapy. $\mathrm{Br} J$ Haematol 2003;122:78-84.

105 Lachmann HJ, Goodman HJB, Gilbertson JA et al. Natural history and outcome in systemic AA amyloidosis. N Engl J Med 2007;356:2361-71.

106 Gillmore JD, Booth DR, Rela M et al. Curative hepatorenal transplantation in systemic amyloidosis caused by the Glu526Val fibrinogen a-chain variant in an English family. QJ Med 2000;93: 269-75.

107 Tennent GA, Brennan SO, Stangou AJ et al. Human plasma fibrinogen is synthesized in the liver. Blood 2007;109:1971-4.

108 Pepys MB, Baltz ML. Acute phase proteins with special reference to C-reactive protein and related proteins (pentaxins) and serum amyloid A protein. Adv Immunol 1983;34:141-212.

The full text of the Harveian Oration is also available in booklet form from the Publications Department of the Royal College of Physicians. 